\title{
The debated question of asymmetrical rhynchonellids (Brachiopoda, Rhynchonellida): examples from the Late Cretaceous of Western Europe
}

\author{
Danièle Gaspard* and Sylvain Charbonnier \\ UMR 7207, Centre de Recherche en Paléontologie, Paris, MNHN-Sorbonne Université-CNRS, Muséum national d'Histoire naturelle, \\ 8 rue Buffon, CP 38, 75005 Paris, France
}

Received: 22 February 2019 / Accepted: 13 November 2019 / Published online: 22 December 2020

\begin{abstract}
Many Cretaceous asymmetrical rhynchonellid brachiopods (Brachiopoda, Rhynchonellida) have long been considered as Rhynchonella difformis (Valenciennes in Lamarck, 1819). After a revision, Owen (1962) included the Cenomanian specimens from Europe in Cyclothyris M'Coy, 1844. Later, Manceñido et al. (2002) confirmed this decision and critically mentioned the name of another asymmetrical rhynchonellid genus from Spain, Owenirhynchia Calzada in Calzada and Pocovi, 1980. Specimens with an asymmetrical anterior margin (non particularly ecophenotypical), from the Late Coniacian and the Santonian of Les Corbières (Aude, France) and Basse-Provence (SE France) are here compared to specimens of the original Cenomanian species C.difformis. They are also compared to new material from the Northern Castilian Platform (Coniacian-Santonian, N Spain) and to Rhynchonella globata Arnaud, 1877 (Campanian, Les Charentes, Dordogne, SW France) and Rh. vesicularis Coquand, 1860 (Campanian, Charente, SW France). These observations document the great morphological diversity among all these species and lead us to erect a new species: Cyclothyris grimargina nov. sp. from the type material of Arnaud, and two new genera: Contortithyris nov. gen. including Contortithyris thermae nov. sp., Beaussetithyris nov. gen. including Beaussetithyris asymmetrica nov. sp. All of these brachiopods fundamentally present an asymmetrical state which origin is discussed.
\end{abstract}

Keywords: Brachiopoda / Rhynchonellida / asymmetry / Late Cretaceous / Western Europe / new genera and species

Résumé - La question débattue des rhynchonelles asymétriques (Brachiopoda, Rhynchonellida): exemples dans le Crétacé supérieur d'Europe occidentale. De nombreuses rhynchonelles asymétriques du Crétacé (Brachiopoda, Rhynchonellida) ont longtemps été considérées comme des Rhynchonella difformis (Valenciennes in Lamarck, 1819). Après une révision, Owen (1962) a inclus les spécimens du Cénomanien d'Europe dans le genre Cyclothyris M'Coy, 1844. Plus tard, Manceñido et al. (2002) ont confirmé cette décision et mentionné de façon critique le nom d'un autre genre asymétrique de rhynchonelles provenant d'Espagne, Owenirhynchia Calzada in Calzada and Pocovi, 1980. Des spécimens avec une commissure antérieure asymétrique (pas particulièrement d'origine écophénotypique), du Coniacien supérieur et du Santonien des Corbières (Aude, France) ainsi que de Basse-Provence (sud-est France), sont comparés ici aux spécimens de l'espèce cénomanienne d'origine, C. difformis. Ils sont également comparés aux spécimens de la plateforme nord-castillane (Coniacian-Santonian, Espagne) et aux spécimens de Rhynchonella globata Arnaud, 1877 (Campanian, Charentes et Dordogne, sud-ouest de la France) ainsi qu'à ceux de Rh. vesicularis Coquand, 1860 (Campanian, Charente, sud-ouest France). Ces observations documentent la grande diversité morphologique de toutes ces espèces et conduisent à la description d'une nouvelle espèce : Cyclothyris grimargina nov. sp. provenant du matériel type d'Arnaud et de deux nouveaux genres: Contortithyris nov. gen. incluant Contortithyris thermae nov. sp. et Beaussetithyris incluant Beaussetithyris asymmetrica nov. sp. Toutes ces rhynchonelles présentent fondamentalement un état asymétrique dont l'origine est discutée.

Mots clés : Brachiopoda / Rhynchonellida / asymétrie / Crétacé supérieur / Europe de l'Ouest / nouveaux genres et espèces

\footnotetext{
*Corresponding author: ds .gaspard@orange.fr; daniele.gaspard@mnhn.fr
} 


\section{Introduction}

Rhynchonelliform brachiopods (Brachiopoda, Rhynchonellida) generally present a bivalved shell with a bilateral symmetry. Variations or deviations from the plane of symmetry are common in rhynchonelliform brachiopods. Numerous authors (e.g., Ager, 1965; Asgaard, 1968; Schumann, 1976, 1991; Asgaard and Bromley, 1991; Afanasjeva, 2014; Schrøeder et al., 2017; Berrocal-Casero et al., 2017) pointed that some variations are in relation to environmental conditions (crowded population, close attachment to a substrate preventing a normal shell growth). Thus, they correspond to an occasional modification of the normal symmetry in the shell, also named dissymmetry. Other variations are also related to particularly shifted/twisted anterior commissures, i.e., shells with a bilobate anterior margin (right side-up/left side-down or the reverse), which seem rather of genetic origin (Fürsich and Palmer, 1984; Gaspard, 1991). This later case corresponds to the lack of normal symmetry in the shell, also named asymmetry. Among the brachiopods, asymmetry is merely observed in rhynchonellids and affects the whole population. Diverse examples have been observed in Jurassic and Cretaceous species (Asgaard, 1968; Fürsich and Palmer, 1984; Gaspard, 1991 and references herein), but the origins of the state of asymmetry remain an open question.

Several rhynchonellids with a right and left-handed asymmetry of the anterior margin are well represented during the Cretaceous (particularly the Middle-Late Cretaceous) till the Danian (Gaspard, 1991). For a long time, most of them have been identified as Rhynchonella difformis (Valenciennes in Lamarck, 1819). After a general revision of Cyclothyris M'Coy, 1844, some of these rhynchonellids have been assigned to Cyclothyris difformis by Owen (1962). This species was documented from numerous localities in the lower-middle Cenomanian of France (Normandy, Sarthe, Indre, Charente and Var), with close comparisons with the specimens of Belgium (Tourtia from Andregnies and Montignies-sur-Roc; Owen, 1962). Other specimens come from western England, particularly from Somerset, Dorset, south Devon (varieties in the sandy lower Cenomanian), southeast Devon (middle Cenomanian), Wiltshire (abundant specimens in the Upper Greensand), Isle of Wight, as well as from Northern Germany (Essen), Bohemian basin (Prague), and from the lower-middle Cenomanian of Bulgaria and from Poland (e.g., Owen, 1962, 1988; Nekvasilova, 1973; PopielBarczyk, 1977; Gaspard, 1991; Motchurova-Dekova, 1994, 1995; Néraudeau et al., 2013).

All the Cretaceous asymmetrical rhynchonellids should not be identified as C.difformis. Among the most common misinterpretations, specimens of Cyclothyris compressa (Valenciennes in Lamarck, 1819) are often misidentified by certain authors as $C$. difformis, (see discussion in Gaspard, 2014). Moreover, asymmetrical rhynchonellids from the Late Cretaceous (Coniacian-Campanian) were also identified as C. difformis. These examples were already discussed (Fürsich and Palmer, 1984; Gaspard, 1991, 2017; Motchurova-Dekova, 1994, 1995). Although Rhynchonella globata Arnaud, 1877 was considered as a possible variant of $R h$. difformis, most of the ancient authors maintained the name, considering that this species pointed a remarkable event: its first occurrence coincides with the early Campanian. In other respects, the type series of Rhynchonella globata appears heterogeneous and needs also a revision.

The aim of the present work is to review and precise the complex situation of the Late Cretaceous (Senonian) asymmetrical rhynchonellids from Les Corbières (Aude, France), Basse-Provence (SE France), Les Charentes and Dordogne (SW France), and Castile (Spain), and to highlight the status of their asymmetry.

\section{Material and methods}

\subsection{Material (Fig. 1)}

Specimens of Cyclothyris difformis have been sampled in the lower Cenomanian layers (glauconitic chalk) in the cliffs of Bec de Caux (Normandy, France), and in the Cenomanian outcrops of Cadeuil in Charente-Maritime, France (Néraudeau coll., Université de Rennes 1: acronym IGR). Specimens from the northeastern Pyrenees come from the Coniacian-Santonian of Rennes-les-Bains and Sougraigne (Fig. 1.1) and were observed in the collections of the Muséum national d'Histoire naturelle (acronym: MNHN.F), Paris. Those from BasseProvence (SE France: Le Beausset, La Cadière, Les Martigues; Fig. 1.2) have been sampled or observed in MNHN collections. Comparisons of Campanian specimens of Rhynchonella globata have been made with the material from the Aquitaine Motorway A10 in Charente (Gaspard, 1985), from Tercis (Landes, France: Gaspard and Odin, 2001), from Les Charentes and Dordogne (Arnaud coll., specimens of the type series in Sorbonne-Université: acronym SU.PAL.) (Fig. 1.3). For comparisons with the Rh. globata type series from the same region, Campanian Rhynchonella vesicularis Coquand, 1860 have been observed in Sorbonne-Université (Arnaud coll.) and MNHN collections. Moreover, the original type material has been also traced in the collection of Mining and Geological Survey of Hungary (acronym MBFSZ).

For other comparisons, Coniacian specimens of Owenirhynchia have been sampled in the Nidàguila Formation at the Villamartin section from the North Castilian platform (Fig. 1.4).

\subsection{Methods}

The specimens sampled are imaged and observed following the external morphology: global shape, details of the anterior margin, shape and number of costae, shape and size of the foramen and details of the deltidial plates. Some of them, selected from each studied area, have been included in an epoxy resin, oriented and then cut to observe the internal characters in sets of transverse serial sections that are drawn using a camera lucida with control of the shell thickness worn out between successive sections.

Two specimens were scanned using X-ray microtomography to complete the study. The radio-transparent substrate on which the specimens are positioned is adjusted to correspond to the axis of the X-ray nano-beam (AST-RX platform, UMS 2700, MNHN, Paris). The specimens were scanned according to the following parameters: (1) specimen MNHN.F.A59944 (Cenomanian, Normandy)-voxel size: $5.977 \mu \mathrm{m}^{3}$, tension: $80 \mathrm{kV}$, intensity: $120 \mu \mathrm{A}$, time exposure: $2000 \mathrm{~ms}$, filtre: $\mathrm{Cu}$ 


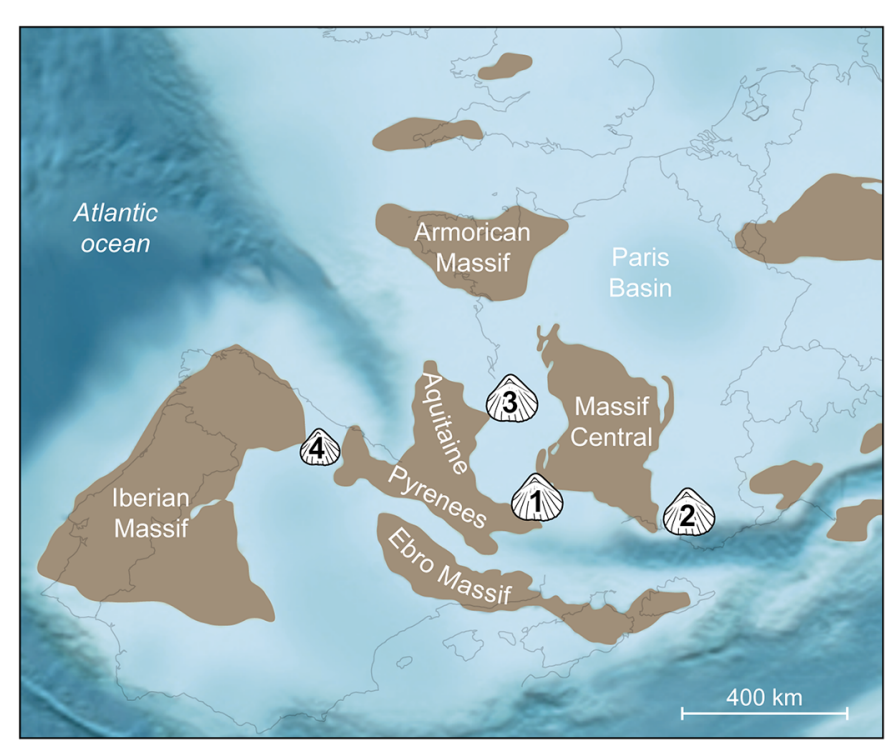

Fig. 1. Location of the Late Senonian asymmetric rhynchonellids observed: (1) Les Corbières (NE Pyrenees); (2) Basse-Provence (SE France); (3) Les Charentes and Dordogne (SW. France); (4) North Castilian Platform. All sites are located on a map extracted from the Paleogeography of Europe Series. Deep Time Maps (2011), Colorado Plateau Geosystems Inc. http://deeptimemaps.com/.

$0.1 \mathrm{~mm}, 1800$ images; (2) specimen MNHN.F.A26502 (Santonian, Basse-Provence)-voxel size: $9.517 \mu \mathrm{m}^{3}$, tension: $110 \mathrm{kV}$, intensity: $50 \mu \mathrm{A}$, time exposure: $2000 \mathrm{~ms}$, filtre: $\mathrm{Cu}$ $0.1 \mathrm{~mm}$ ) (for videos and successive virtual transverse sections, see online Appendices A-D).

Several other scanned specimens were too recrystallized to allow a 3D reconstruction, even a clear individualization of internal characters in virtual sections (see Gaspard, 2013).

In order to highlight details at the sites of the articulation (dental sockets, dental plates), hinge plates, crura, and dorsal septum, and to precise the orientation of the fibrous elements forming the low Mg-calcite secondary layer of the shell, some selected transverse sections were observed using a scanning electron microscope (JEOL SEM; MNHN, Sorbonne Université). These sections were observed after polishing, light acid attack (a few seconds with $12.5 \%$ rapid decalcifier RDC Laboratoire Moderne $^{\odot}$ ) and gold coating (see online Appendix E).

\section{Geological setting}

\subsection{Northeastern Pyrenees (Les Corbières) (Fig. 1.1)}

The asymmetrical rhynchonellids from Les Corbières were first mentioned by d'Orbigny (1847-1851), d'Archiac (1854), Coquand (1860), Toucas (1880), Péron (1877), Fage (1934), Sénesse (1937) and Basse (1939). All these authors reported the presence of Rhynchonella difformis from the late Coniacian to the early Santonian.

In the present study, the asymmetrical rhynchonellids are mainly found in the Marnes à Micraster Formation at Rennesles-Bains (Aude) and in the Marnes bleues de Sougraigne Formation at Sougraigne (Aude). The Marnes à Micraster
Formation is middle Coniacian-middle Santonian in age and the Marnes de Sougraigne Formation is middle-late Santonian in age (Bilotte and Freytet, 1984). More precisely, the asymmetrical rhynchonellids of the Marnes à Micraster Formation are mainly found in the early Santonian Nowakites carezi ammonite biozone, and in the basal part of the earlymiddle Santonian Texanites gallicus ammonite biozone (Hancock, 1991; Kennedy et al., 1995).

\subsection{Basse-Provence (SE France) (Fig. 1.2)}

The asymmetrical rhynchonellids from Basse-Provence were first mentioned by d'Orbigny (1847-1851), Toucas (1873, 1885), Vasseur (1894) and later by Babinot (1980), Tronchetti (1981), Babinot et al. (1984) and Grosheny (1986). After several discussions about the age of the outcrops, most of these authors reported the presence of Rhynchonella difformis in the Santonian of the region.

In the present study, the asymmetrical rhynchonellids have been found in La Cadière Formation at Le Moulin-de-laCadière (early Santonian, Grosheny, 1986) and in the Santonian at Le Beausset, Le Castellet and Les Martigues (Babinot et al., 1984).

\subsection{Les Charentes and Dordogne (SW France) (Fig. 1.3)}

The asymmetrical rhynchonellids from Les Charentes were collected in the Cenomanian of Cadeuil (Charente Maritime). A well-preserved specimen of Rhynchonella difformis illustrated by Néraudeau et al. (2013: pl. 12d-e), shown here, is compared with the lower-middle Cenomanian specimens from the lectotype area (Normandy).

In other respects, specimens of Rhynchonella globata were either observed in collections or collected in the Campanian from Les Charentes and Dordogne. The type series listed by Arnaud (1877) appears heterogeneous and requires an in-depth study. Specimens of Rhynchonella vesicularis from the Campanian of Les Charentes (Aubeterre-sur-Dronne) and from Dordogne (Beaufort, Issac, Puyvigier, Sourzac) were also observed, including the type material.

\subsection{North-Castilian Platform (Spain) (Fig. 1.4)}

Asymmetrical rhynchonellid brachiopods have been found in the Upper Cretaceous of the North-Castilian Platform which geological setting is described in detail by Floquet (1978, 1991), Floquet et al. (1982) and Lamolda et al. (2002). The studied specimens were collected in the Nidáguila Formation at Villamartin section (Gaspard, 2010) and identified as Owenirhynchia Calzada in Calzada and Pocovi, 1980 by Lamolda et al. (2002), but as Cyclothyris aff. globata by Berrocal-Casero et al. (2017). More precisely, these asymmetrical rhynchonellids are late Coniacian in age (Floquet, 1991). Muñoz (1985, 1994) also recognized representatives of Owenirhynchia, later introduced by Manceñido et al. (2002) as a possible subgenus or a subjective synonym of Cyclothyris. 


\section{Systematic palaeontology}

Brachiopoda Duméril, 1805

Rhynchonellida Kuhn, 1949

Hemithyridoidea Rzhonsnitskaia, 1956

Cyclothyrididae Makridin, 1955

Emended diagnosis after Manceñido et al. (2002). Trilobate, sharply costate Hemithiridoidea, with anterior commissure uniplicate or sometimes asymmetrical; lamellose ornament frequently developed; squamma-glotta obsolescent. Middle Triassic-Late Cretaceous.

Cyclothyridinae Makridin, 1955

Emended diagnosis after Manceñido et al. (2002). - Fully costate Cyclothyrididae, rarely with posterior smooth area, beak massive, with large hypothyrid rimmed foramen (i.e., deltidial plates produced into short tube around pedicle). Dorsal median septum usually very much reduced, septalium reduced or absent, crura canaliform (or at least distally concave modified raduliform). Characteristically strongly and densely costate. Middle Triassic-Late Cretaceous.

\section{Cyclothyris M'Coy, 1844}

Type species. - Terebratula latissima J. de C. Sowerby, 1829, by subsequent designation of Buckmann (1906).

Emended diagnosis after Manceñido et al. (2002). Medium to large, wide, with uniplication low, arcuate, commonly asymmetrical; costellae numerous, fine posteriorly, beak erect, foramen large, auriculate, deltidial plates conjunct, well exposed. Dorsal septum short or absent; hinge plates distally concave; crura long, dorsally concave.

\section{Cyclothyris difformis (Valenciennes in Lamarck, 1819) \\ Figures 2 and 3}

Terebratula difformis Valenciennes in Lamarck, 1819: 255. not Rhynchonella difformis. d'Orbigny 1847-1851: 41-43, pl. 498, figs. 6-9.

Cyclothyris difformis. Owen 1962: 51, pl. 1, figs. 1-7. [lectotype selection]. - Owen 1988: 84, pl.1, figs. 13-15, pl. 2, figs. 4-6, 10-15.

Type material - Lectotype selected by Clerc and Fabre (1918). It comes from the lower Cenomanian of Normandy coast (France) and is housed at the Muséum d'Histoire Naturelle, Geneva, in the Lamarck collection (for details see Owen, 1962).

Examined material from the Cenomanian - Five specimens MNHNF.A67478-A67480, A59944, A70585 (Gaspard coll.) from the cliffs of Cap de la Hève, Pays de Caux, Normandy (Figs. 2A-2N and 3; Appendices A-C); one specimen IGR23222 (Néraudeau coll). from the lower Cenomanian, of Cadeuil (Charente-Maritime) (Figs. 2O-2Q); specimens observed in situ from the middle Cenomanian of Île Madame (Charente-Maritime).

Description of external morphology (Fig. 2) - The medium-sized to large biconvex shell is wider than long, the ventral beak is sub-erect (slightly incurved) never approaching the dorsal umbo. Sometimes, the beak seems to be more inclined and longer on one side or the other. The foramen is round with a diameter of 1-2 mm bounded by the exposed deltidial plates, not conjunct at the juvenile stage (Figs. 2A and 2D), twice large at the anterior part and whose lateral expansions form a short tube in

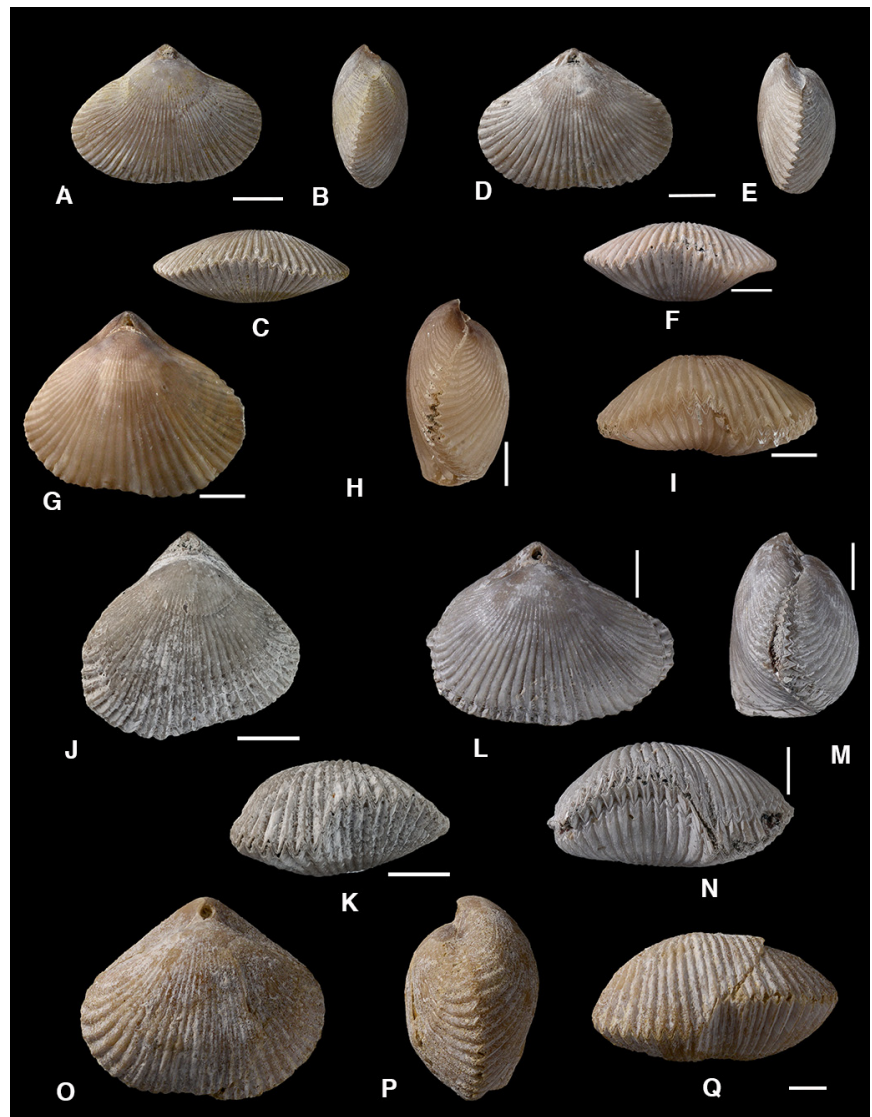

Fig. 2. Cyclothyris difformis (Valenciennes in Lamarck, 1819). A-N Five specimens (Gaspard coll.) from the Cenomanian of Normandy (Cap de la Hève, France). A-C. Dorsal (A), lateral (B), and anterior (C) views of a juvenile specimen MNHN.F.A67478 with a faintly rectimarginate anterior margin. D-F. Monoplicate juvenile/preadult specimen MNHN.F.A67479. G-I. Adult specimen MNHN.F.A67480 showing right-asymmetrical anterior commissure. J, K. Small adult specimen MNHN.F.A70585 showing left-asymmetrical anterior commissure. L-N. Scanned specimen MNHN.F.A59944 (for video and virtual transverse and longitudinal sections see online Appendices A-C). O-Q. Specimen IGR23222 (Néraudeau coll.) from the Early Cenomanian of Cadeuil (Charente-Maritime, France). Photographs: P. Loubry. Scale bars $=5 \mathrm{~mm}$.

adults (Figs. 2J, 2L, 2O). The shell is flat in juvenile stages (Figs. $2 \mathrm{~B}$ and $2 \mathrm{E})$. The lateral commissures are nearly straight with a deflection anteriorly in adults (Figs. 2B, 2E, 2H, 2M). The anterior commissure is rectimarginate in juvenile stages (Fig. 2C) then, progressively monoplicate (Fig. 2F) tending to become asymmetric in a more pronounced way in adults: right sidedown/left side-up (Figs. 2I and 2N) or the reverse (Figs. 2K and 2Q). Numerous costae, small and round in juveniles then sharper and higher near the commissures (at least 30-45 in adults) ornament the shell, one to three of them take place along the shift between the side-up and the side-down of the anterior commissure.

Description of internal characters - The transverse serial sections of specimen MNHN.F. MNHN.F.A70934 (Fig. 3), and the virtual transverse and lateral views from the scanned specimen MNHN.F.A59944 (Appendices A-C) reveal: welldefined deltidial plates with the lateral expansions (Figs. 3a-3d), 


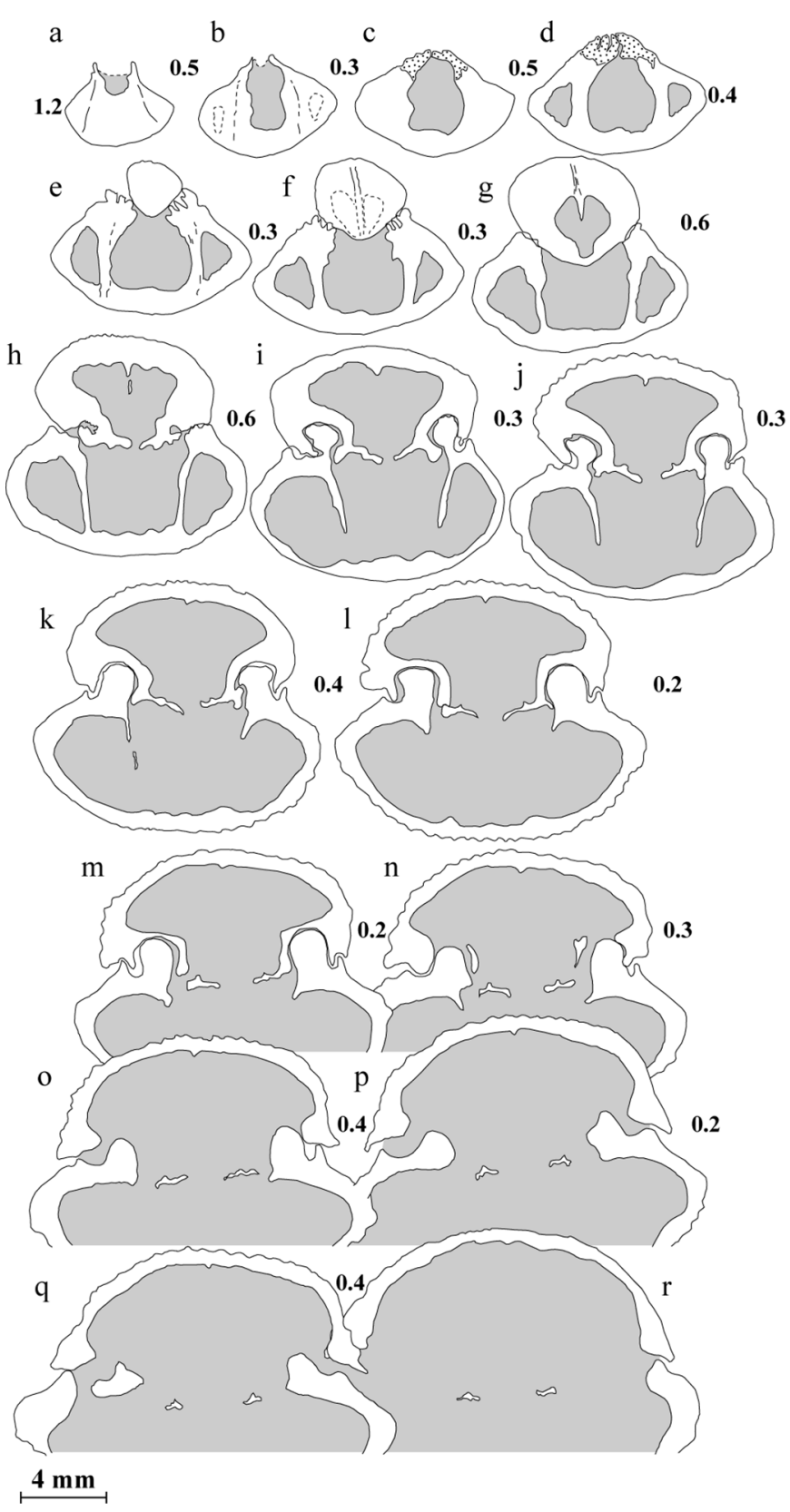

Fig. 3. Transverse serial sections in a shell of Cyclothyris difformis (MNHN.F.A70934, Cap de la Hève, Normandy, France) with a length of $25.0 \mathrm{~mm}$. Internal characters from the posterior shell to the level of the crura. Each section is labelled with a letter and the worn thickness between two successive sections is indicated in millimetre (this mention is valid for all sets of transverse serial sections). Line drawings: D. Gaspard.

thick nearly parallel dental plates (Figs. 3d-3j), posterior sharppointed expensive dorsal septum (Figs. $3 \mathrm{f}-3 \mathrm{j}$ ) then deceasing (Figs. 3k-3q), thick hinge teeth with small and brief lateral accessory teeth inserted in deep dental sockets and accessory counter parts (Figs. 3i-3n), slightly concave hinge plates, and raduliform to canaliform crura (Figs. $3 m-3 r$ ).

Comments. - Cenomanian specimens referred to Cyclothyris difformis as reported by Néraudeau et al. (2013) present

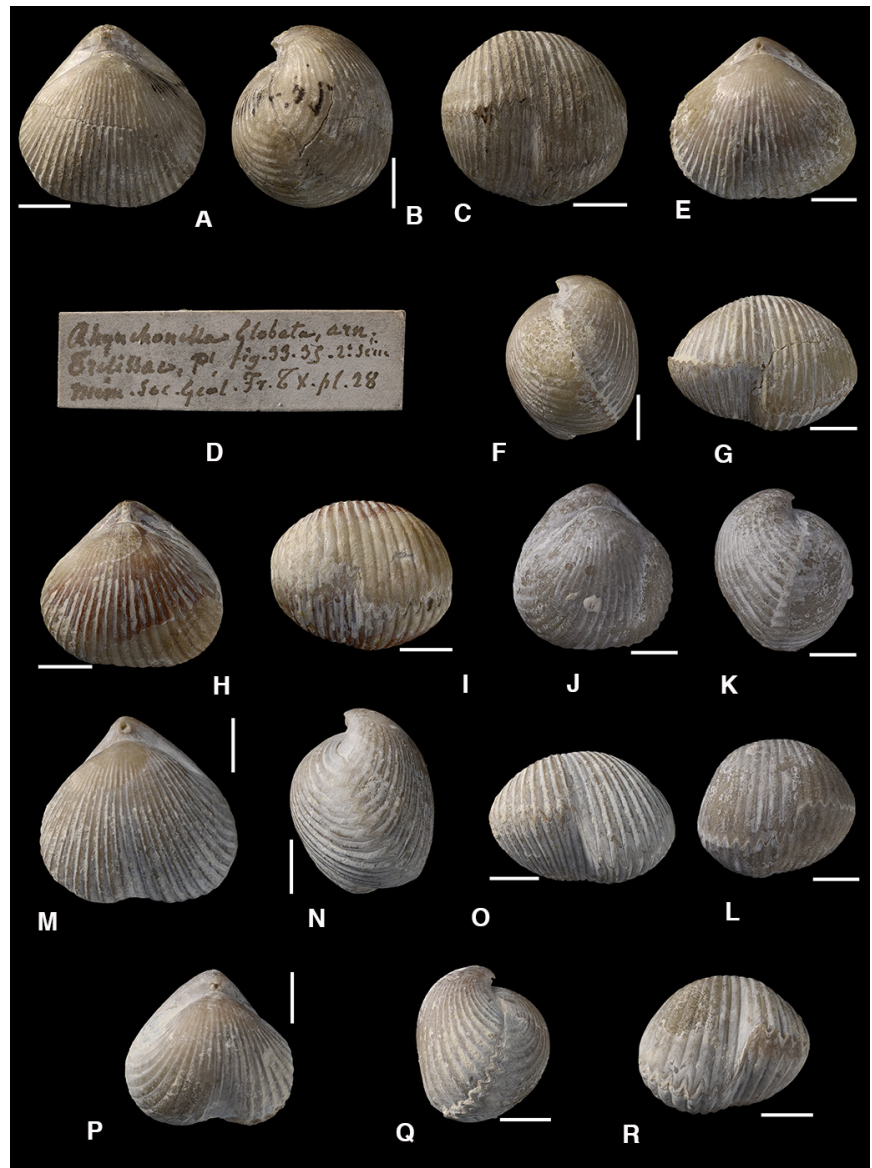

Fig. 4. Cyclothyris globata (Arnaud, 1877) from the Campanian of Les Charentes and Dordogne (France). A-C. Dorsal, lateral and ventral views of the lectotype SU.PAL.2018.0.55.29.1 from Trélissac. D. Original label of the lectotype. E-G. Paralectotype SU. PAL.2018.0.55.29.2 from Trélissac. H-I. Paralectotype SU. PAL.2018.0.55.29.3 from Trélissac. J-L. Specimen MNHN.F. A59949 (Gaspard coll.) from Eraville. M-O. Specimen SU. PAL.2018.0.55.138.1 (Arnaud coll.) from Viville, note also the dissymmetry of the shell. P-R. Specimen SU.PAL.2018.0.55.44.1 (Arnaud coll.) from Mainfonds. Photographs: P. Loubry except M-O: L. Cazes. Scale bars $=5 \mathrm{~mm}$.

the same characteristics as those from Normandy. When well preserved, the material from the basal Cenomanian of Cadeuil is comparable in size and global shape with that from Normandy, the differences rest in the more rounded anterior part and a less deflection on one or the other side of the anterior margin (Fig. 2Q). We point out that assymmetrical specimen MNHN.F.A70585 (Figs. 2J and 2K) is also affected by a dissymmetry well visible in the dorsal and frontal views.

Cyclothyris globata (Arnaud, 1877)

Figures 4 and 5; Table 1

Rhynchonella globata Arnaud, 1877: 83, pl. 8, figs. 33-35. not Rhynchonella globata. Arnaud, 1877: 83, pl. 8, figs. 36-38.

not Rhynchonella difformis var. globata. Fage 1934: 439, pl. 23, fig. $\mathrm{Dg}^{1-5}$.

Cyclothyris aff. globata. Muñoz 1985: 43, pl. 1, fig. 2. 

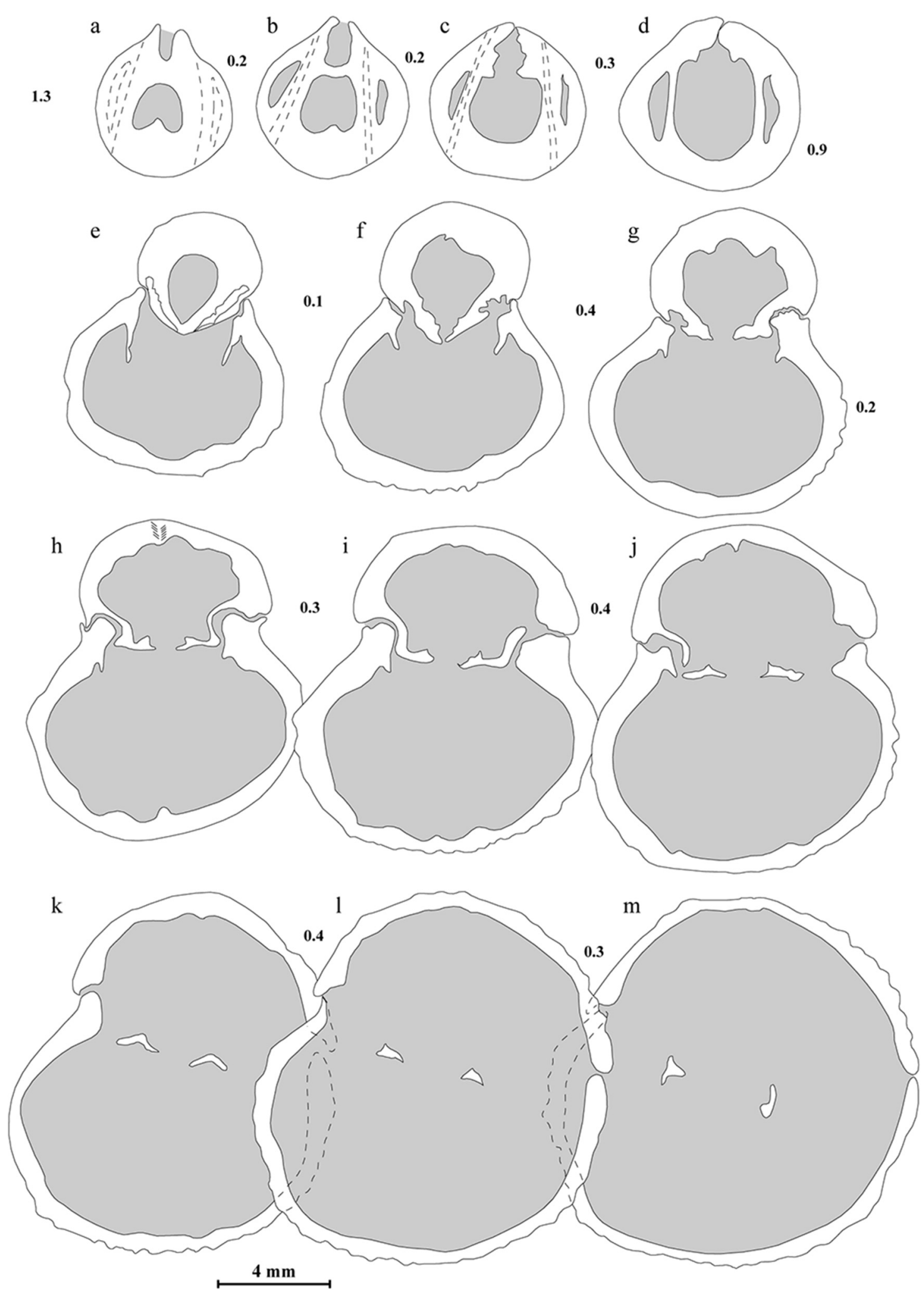

Fig. 5. Transverse serial sections in a shell of Cyclothyris globata (Arnaud, 1877) (MNHN.F.A70935) from the Campanian of Cavillac (Dordogne), with following measurements: $18.3 \mathrm{~mm}$ in length, $19.3 \mathrm{~mm}$ in width, $14.6 \mathrm{~mm}$ in thickness. Internal characters from the posterior shell till the level of the crura. Line drawings: D. Gaspard. 
Table 1. List of the type material and additional specimens of Cyclothyris globata from the Campanian of Les Charentes and Dordogne. Stratigraphical levels P1-P3 of Arnaud (1877) correspond to biozones CI-CV of the Campanian sensu Platel (1977, 1982).

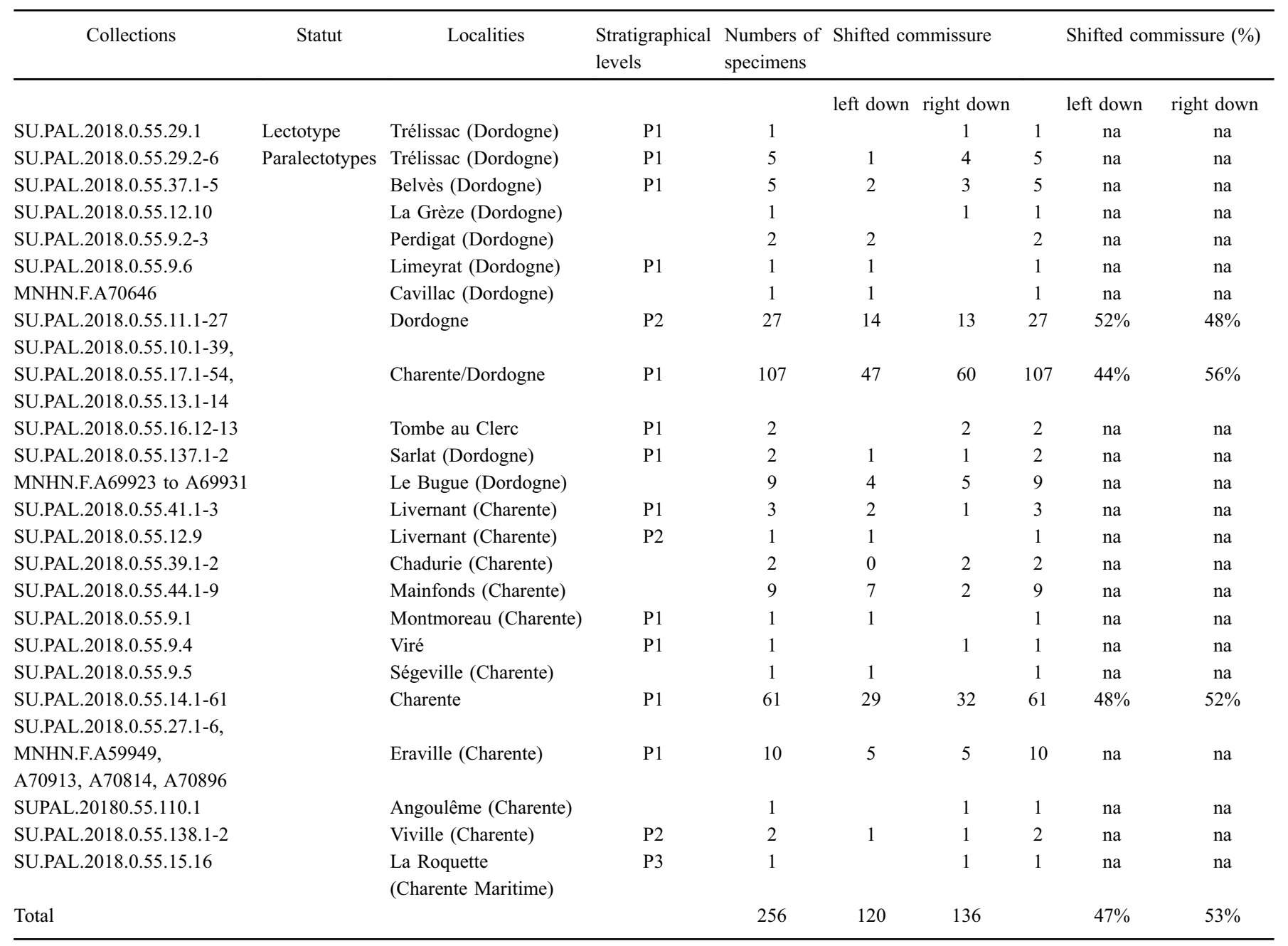

Rhynchonella globata. Gaspard 1991: pl. 1, fig. 10 (non figs. 7-9).

Owenirhynchia globata. Muñoz 1994: 154, fig. 64.

not Cyclothyris globata. Motchurova-Dekova 1995: pl. 4, 5. Gaspard and Odin, 2001: pl. 1.1.

not Cyclothyris aff. globata. Berrocal-Casero et al., 2017: 80, fig. 4.

Type material. - The original type material of Arnaud (1877) was composed of a non-assessable number of Campanian specimens from a large set of localities from Les Charentes and Dordogne (SU.PAL.2018.0.55.9.0 to SU. PAL.2018.0.55.44.0; see Tab. 1). Among them, the specimen SU.PAL.2018.0.55.29.1 (figured by Arnaud, 1877: pl. 8, figs. 33-35) is herein selected to be the lectotype (Figs. 4A-4D). Several paralectotypes have been identified and fit the original diagnosis of Arnaud (1877). They are listed in Table 1 and some of them are illustrated in Figures 4E-4R.

Type locality. - Trélissac, Dordogne, France.

Among the paralectotypes, some localities are handlabelled by Arnaud (1877) and others are unfortunately groups of specimens without precise locality in Charente or Dordogne (see Tab. 1).

Type age. - Campanian (levels P1-P3 of Arnaud 1877 corresponding to benthic foraminiferal biozones CI-CV of Platel, 1977).

Additional examined material from the Campanian - see Table 1.

Description of external morphology (Fig. 4) - Medium sized (length: 11.4-20.6 mm; width: 13.9-23.4 mm; thickness: $10.3-17.7 \mathrm{~mm}$ ), rounded shells with a curved ventral beak (Figs. 4B, 4F, 4K), ornamented by about 27-30 to 38 costae (number which is not always in correlation with the shell size). The ventral umbo is curved somewhat sharp-pointed and sometimes nearly reaching the dorsal umbo (Fig. 4Q), the limit of the joined deltidial plates bounding the small foramen (diameter around $1 \mathrm{~mm}$ in adults, even less in some cases) is visible. Sometimes the lateral expansions of these deltidial plates are best developed, although less than in C. difformis. The dorsal area on each side of the deltidial plates is smooth except a few fine growth-lines. The lateral commissure is more 

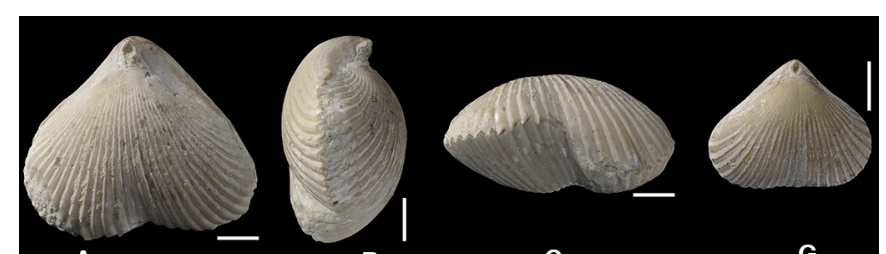

A

B
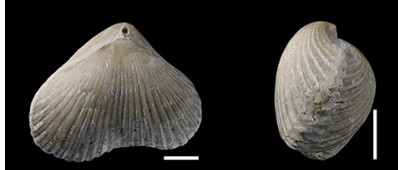

C

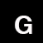

D

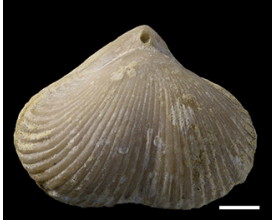

E

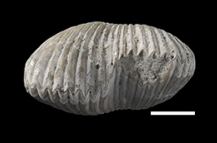

$\mathbf{F}$

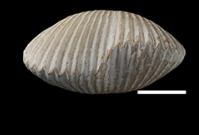

H
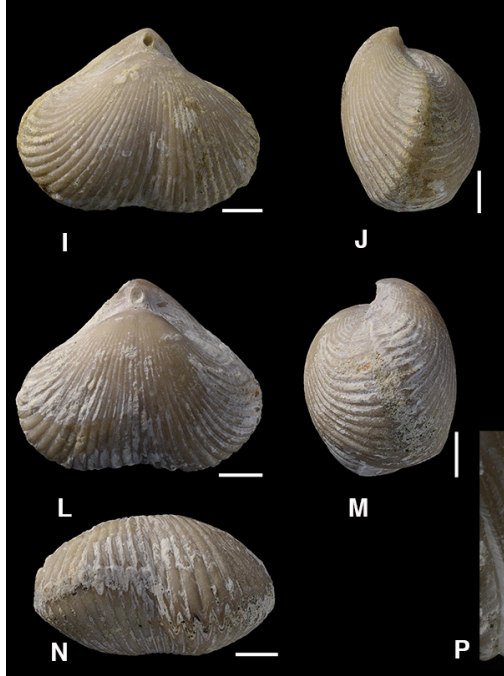

J
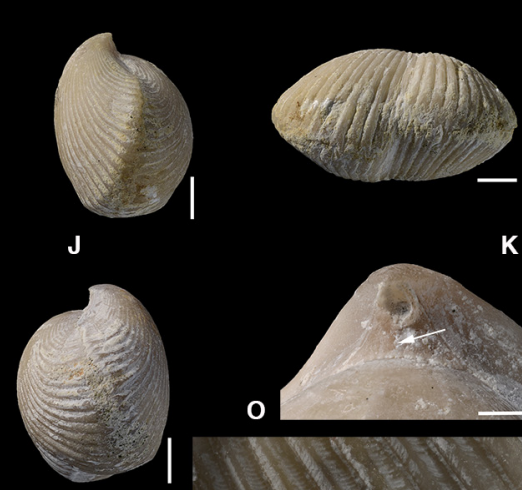

M

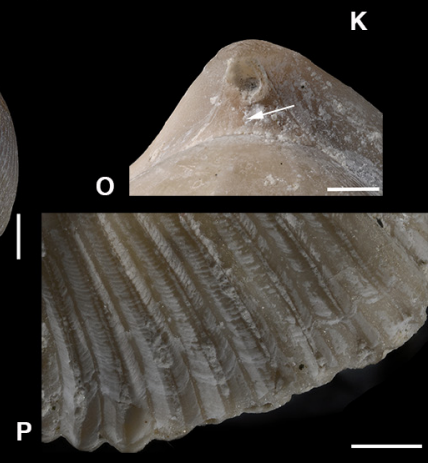

Fig. 6. Cyclothyris grimargina nov. sp. from the Campanian of Les Charentes and Dordogne, France (Arnaud coll.). A-C. Dorsal, lateral and anterior views of the holotype SU.PAL.2018.0.55.19.1 from Caillaud, Charente-Maritime. D-F. Specimen SU.PAL.2018.0.55.11.28 from Charente. G,H. Specimen SU.PAL.2018.0.55.11.29 from Charente. IK. Specimen SU.PAL.2018.0.55.28.1 from Périgueux. L-O. Specimen SU.PAL.2018.0.55.28.3 from Périgueux with close-up view of the conjunct deltidial plates (O, see white arrow). P. Close-up view of costae and elementary growth marks on them revealed on specimen SU. PAL.2018.0.55.28.6 from Périgueux. Scale bars $=5 \mathrm{~mm}$, except $(\mathrm{O}$, P) $=2 \mathrm{~mm}$. Photographs: P. Loubry.

or less inclined ventrally (Figs. 4B, 4F, 4K, 4N, 4Q). The shifting of the lateral lobes of the anterior margin, left-up/rightdown or the reverse, is most often revealed along about one costa (Figs. 4C, 4G, 4I, 4R).

Description of internal characters (Fig. 5) - Specimen MNHN.F.A70935: pedicle collar present, thick dental plates rapidly thinning down (Figs. 5a-5f), thick hinge teeth inserted in wide dental sockets (Figs. 5g-5j), slightly concave hinge plates (Figs. $5 \mathrm{~g}-5 \mathrm{j}$ ), raduliform to canaliform crura (Figs. $5 \mathrm{k}-5 \mathrm{~m}$ ).

Comments. - Muñoz (1994) proposed the new combination Owenirhynchia globata and was followed by several authors until Berrocal-Casero et al. (2017). The globose shape of all the type specimens and new specimens observed in this study is not compatible with the original diagnosis of Owenirhynchia. Indeed, these last authors precised that Owenirhynchia presents shells not globose, generally larger than longer, with

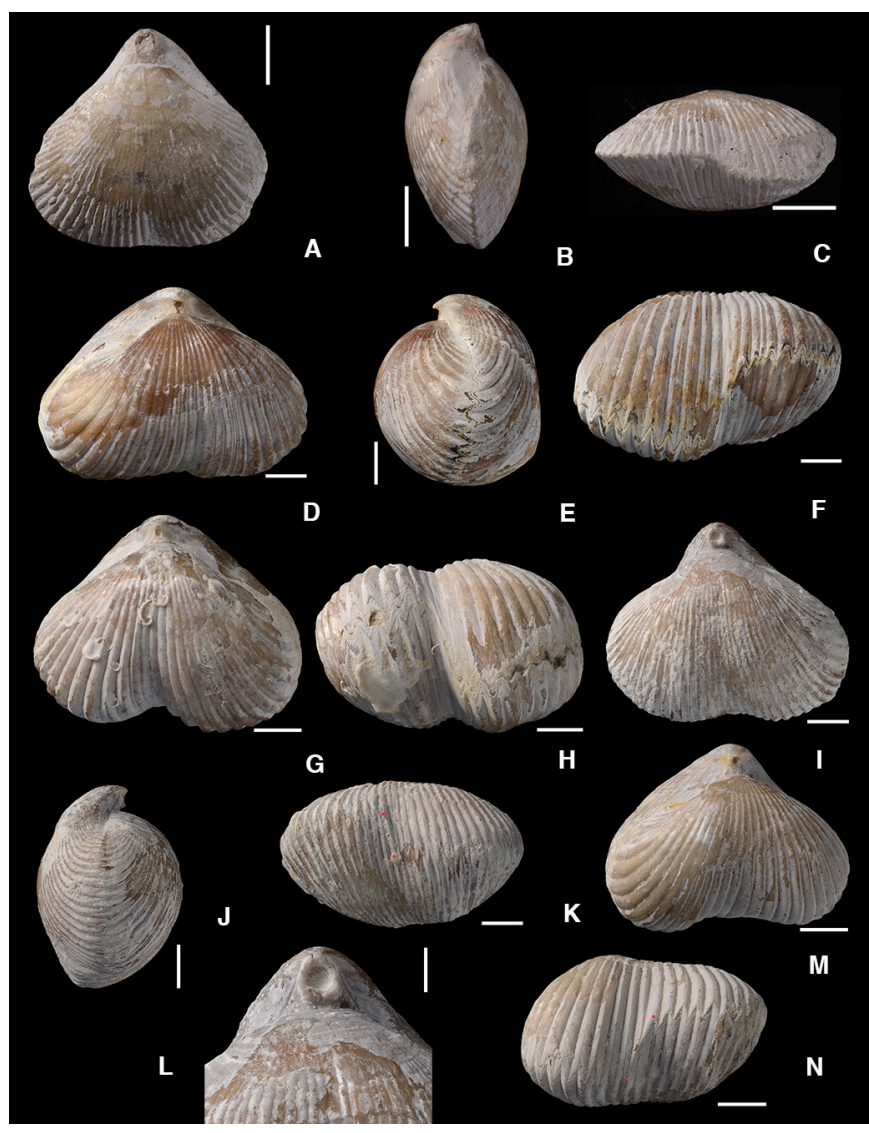

Fig. 7. Cyclothyris grimargina nov. sp. from the Campanian of Les Charentes and Dordogne. A-C. Subadult specimen MNHN.F.A70790 (Late Campanian from the road between Barbezieux and Barzan; Villier coll.). D-F. Specimen SU.PAL.2018.0.55.46.1 from Mensignac. G-H. specimen SU.PAL.2018.0.55.46.2 from Mensignac. IL. Specimen SU.PAL.2018.0.55.34.2 from Caillaud/Talmont: the red dots precise the limits of the shifting; close-up view of the posterior shell with the wide rimmed foramen (L). M,N. Specimen SU. PAL.2018.0.55.36.2 from Saint-Hilaire (Charente). Scale bars $=5$ $\mathrm{mm}$, except $(\mathrm{L})=2 \mathrm{~mm}$. Photographs: P. Loubry.

subtriangular outline [literal translation of "conchas no globulosas, generalmente más anchas que largas de contorno subtriangular']. We propose an assignment to Cyclothyris based on the shape deltidial plates whose lateral expansions form a tube.

Radulović and Motchurova-Dekova (2002) identified specimens of Cyclothyris? globata from the SantonianCampanian of southeastern Europe (Pannonides, CarpathoBalkanides, Dinarides). We note that until now this species is restricted to the Campanian and that some identifications proposed for the Santonian outcrops should be review.

Cyclothyris grimargina nov. sp.

Figures 6-8; Table 2

Rhynchonella difformis var. globata. Fage 1934: pl. 22, fig. $\mathrm{Dg}^{1-5}$.

Rhynchonella globata. Gaspard 1991: pl. 1, figs. 7-9.

Etymology. - The specific epithet is a contraction of the Old Frankish grima (mask) and the Latin margo (commissure). 

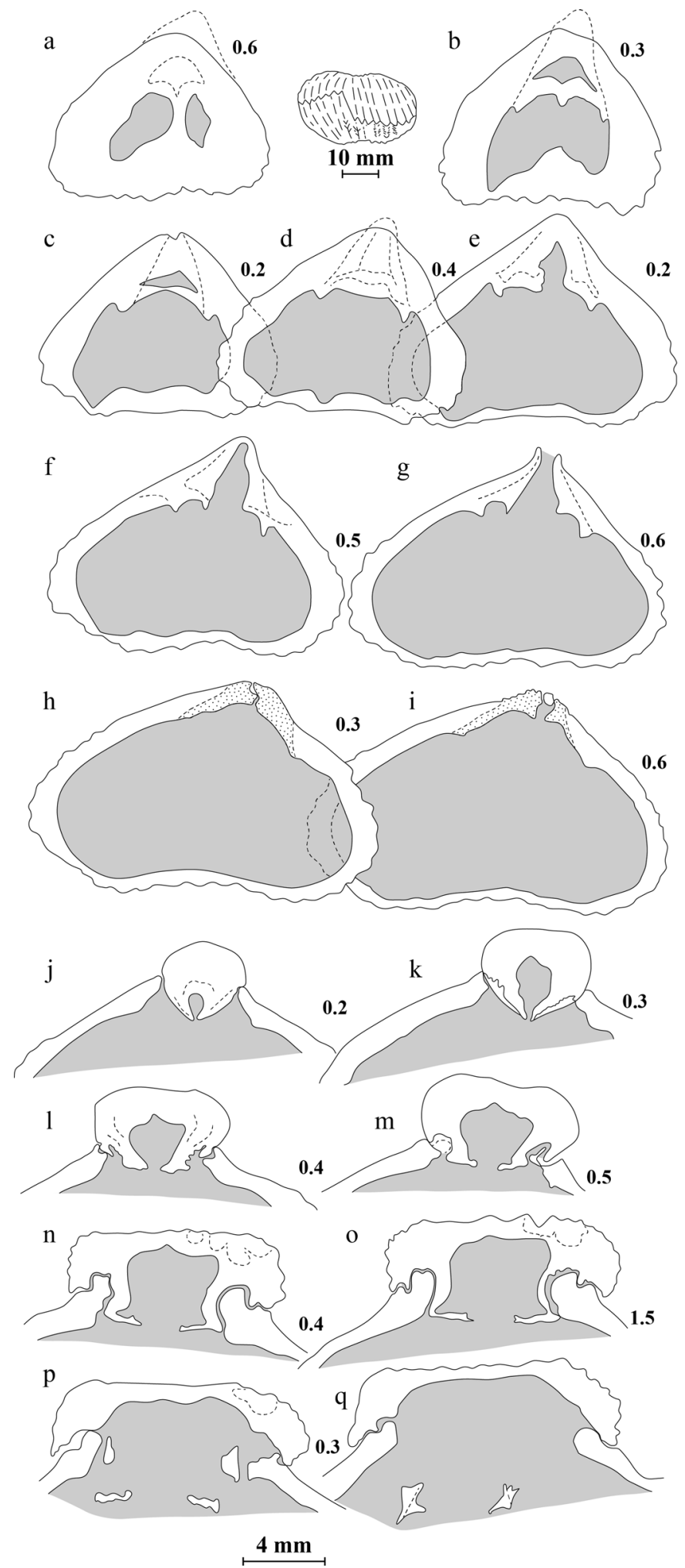

Fig. 8. Transverse serial sections in a shell of Cyclothyris grimargina nov. sp. (MNHN.F.A70936) from the Campanian of Gurat (Charente) (measurements: $21.3 \mathrm{~mm}$ in length, $31.3 \mathrm{~mm}$ in width, $18.6 \mathrm{~mm}$ in thickness). Line drawings: D. Gaspard.
Type material. - Holotype SU.PAL.2018.0.55.19.1. Several paratypes are listed in Table 2.

Type locality. - Caillaud, Charente-Maritime, France.

Type age. - Campanian.

Additional examined material from the Campanian. - See Table 2.

Diagnosis. - Biconvex globose and strongly costate shell with a wide-wing shape; conjunct deltidial plates whose lateral expansions form a tube; suberect to slightly curved ventral beak, asymmetric anterior margin with a more or less inclined shift line.

Description of external morphology (Figs. 6 and 7) - Wide sized subtriangular shells (length: $11.4-26.7 \mathrm{~mm}$; width: 12.1 $32.4 \mathrm{~mm}$; thickness: $08.0-19.3 \mathrm{~mm}$ ) with a medium curved to suberect pointed ventral beak (Figs. 6B, 6J, 6M, 7B, 7E), ornamented by about 27 to 38 coarse costae, exceptionally 50 (Figs. 6A, 7D, 7I, 7M) round and finer in the posterior shell, sharper and wider near the margins. The limit of the joined deltidial plates is visible (Figs. $6 \mathrm{O}$ and $7 \mathrm{~L}$ ); these later line the round foramen (around $1.5 \mathrm{~mm}$ in diameter). The lateral expansions of these deltidial plates are developed to form a short tube. The dorsal areas of the ventral beak are smooth except very fine growth lines. The shifting of the lateral lobes of the anterior margin left-up/right-down, or the reverse, is most often revealed along around two to four costae (Figs. 6C, $6 \mathrm{~F}, 6 \mathrm{~K}, 6 \mathrm{~N}, 7 \mathrm{~F}, 7 \mathrm{H}, 7 \mathrm{~K}, 7 \mathrm{~N})$. Lateral margins more often inclined ventrally in the anterior shell part (Figs. 6E, 6J, 6M). Sometimes elementary growth lines are observed at the midanterior shell surface (Fig. 6P). Notice that subadult specimens reveal a proportional wider foramen (Fig. 7A), are flatter with straight lateral margins (Fig. 7B), a lateral and anterior end of valves forming a sharp angle and an anterior margin slightly asymmetrical with a weak shift (Fig. 7C).

Description of internal characters (Fig. 8) - Specimen MNHN.F.A70936: pedicle collar present, ephemeral dental plates, rapidly disappearing. Deltidial plates well-marked (Figs. 8g-8j), semi-rounded to sub-flattened dorsal posterior shell (Figs. 8j-8q), nearly constricted hinge teeth closely inserted in the dental sockets (Figs. 81-8o), slightly concave hinge plates evolving to a subhorizontal position anteriorly (Figs. $8 \mathrm{~m}-8 \mathrm{o}$ ), thick raduliform to canaliform crura (Figs. $8 \mathrm{p}-8 \mathrm{q})$.

Discussion. - This species is assigned to Cyclothyris based on the following characters: asymmetrical anterior commissure, deltidial plates forming short tube around foramen, beak suberect to slightly curved. It differs from Cyclothyris difformis by a stronger asymmetry with a well-developed lateral right/left shift at the level of anterior commissure forming two distended lobes sometimes unequal. It differs from Cyclothyris globata by the wing-shaped shells (very round globose shell in C.globata), the orientation of the shifting line (more inclined) of the anterior commissure and the stronger costae. It differs from Cyclothyris vesicularis by a straight thinner ventral beak, more and finer costellae and an asymmetric anterior margin rather slightly twisted than obliquely shifted in this last species. Cyclothyris vesicularis is in a whole relatively slender than Cyclothyris grimargina nov. sp. 
Table 2. List of the type material and additional specimens of Cyclothyris grimargina nov. sp. from the Campanian of Les Charentes and Dordogne. Stratigraphical levels P1-P3 of Arnaud (1877) correspond to biozones CI-CV of the Campanian sensu Platel (1977, 1982).

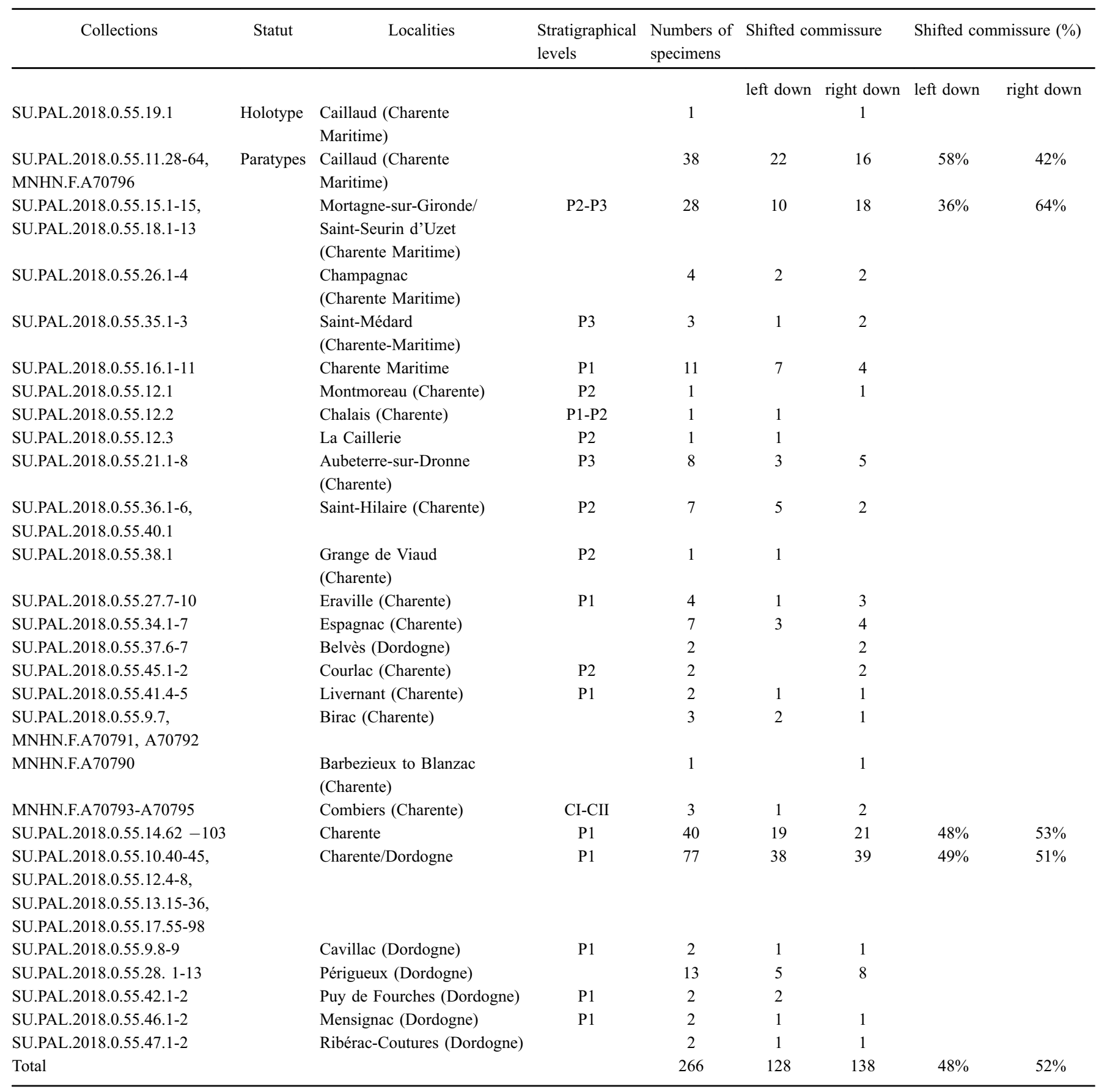

Cyclothyris vesicularis (Coquand, 1860)

Figures 9-11

Terebratula vesicularis Coquand, 1860: 122.

Rhynchonella vesicularis. Coquand, 1862: 332, 338, pl. 34, figs. 7-9.

Type material. - The original type material was composed of a few number of specimens from Aubeterre-sur-Dronne, Charente, France. Four syntypes have been traced in the palaeontological collections of the Mining and Geological Survey of Hungary at Budapest. Among them, specimen MBFSZ K 2019.10.4.1 is here selected to be the lectotype (Figs. 9A-9C). Two paralectotypes MBFSZ K 2019.10.4.3 and K 2019.10.4.4 (Figs. 9D-9F) are also considered. The last specimen MBFSZ K 2019.10.4.2 shows strong costae and thus probably does not belong to the species.

Type locality. - Aubeterre-sur-Dronne, Charente, France. Type age. - Campanian 


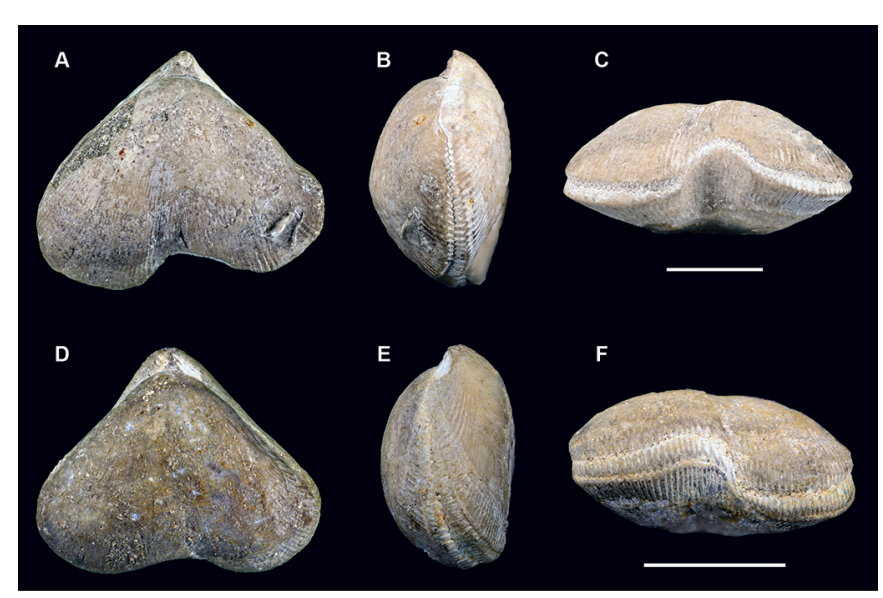

Fig. 9. Type material of Cyclothyris vesicularis (Coquand, 1860) from the Campanian of Aubeterre-sur-Dronne, Charente, France. AC. Lectotype herein designated (MBFSZ K 2019.10.4.1, Coquand coll.). D-F. Paralectotype MBFSZ K 2019.10.4.4. Scale bars $=1 \mathrm{~cm}$ Photographs: Zoltán Lantos.

Examined material. - Three specimens MNHN.F.A70583, A70584, S08809 (Péron coll.) from Aubeterre-sur-Dronne (Charente). A set of well-preserved specimens (Arnaud coll.) from Aubeterre-sur-Dronne (SU.PAL.2018.0.55.21.1-8), Puyvigier, (SU.PAL.2018.0.55.22.1-3), Beaufort (SU. PAL.2018.0.55.23.1-3), Issac (SU.PAL.2018.0.55.24.1-4), Sourzac (SU.PAL.2018.0.55.25.1-7).

Description of external morphology (Figs. 9 and 10) Large specimens globally triangular (length: 17.0-31.5 mm; width: $19.4-40.9 \mathrm{~mm}$; thickness: 11.9-20.1 mm) (Figs. 10A, $10 \mathrm{D}, 10 \mathrm{G}, 10 \mathrm{~J})$, with a straight suberect to slightly incurved ventral beak (Figs. 10B, 10E, 10N), the maximum width in anterior position (Figs. 10A, 10D, 10J, 10M), a variable sized foramen (diameter: around $1 \mathrm{~mm}$, sometimes more) lined by well-defined lateral expansions of the deltidial plates (Fig. 10I), and a typical twisted asymmetrical anterior margin (Figs. 10C, $10 \mathrm{~F}, 10 \mathrm{H}, 10 \mathrm{~L}$ ). The shell is ornamented by 75 to 98 (even 100) costellae, fine posteriorly whose size increases near the margins revealing sometimes a gerontic aspect, even exaggerated in a mid-depressed anterior margin (Fig. 10O) and an unsual gathering of two or three fine costellae in a strong one (Figs. 10O-10P). The costellae present sometimes a digitation at midlength (see Fig. 10J). In this species a longer lateral margin is observed where the down side lobe of the anterior commissure is concerned. Often the lateral and anterior margins are slightly depressed (Figs. 10C, 10F, 10L, 10O).

Description of the internal characters (Fig. 11) - Specimen MNHN.F.A70937 (length: $22.3 \mathrm{~mm}$; width: $28.0 \mathrm{~mm}$; thickness: $17.6 \mathrm{~mm}$ ): strong dental plates (Figs. 11b-11i), developed deltidial plates (stippled) (Figs. 11f-11h), an ephemeral dorsal septum (Figs. $11 \mathrm{j}-11 \mathrm{n}$ ), dental sockets deep and slightly crenulated posteriorly and wide anteriorly (Figs. 11j-11o), constricted then thick hinge-teeth (Figs. 11k-11o), hinge plates convex dorsally (Figs. $11 \mathrm{k}-11 \mathrm{p}$ ), and crura distally raduliform (Figs. 11p-11r).

Contortithyris nov. gen.

Type species. - Contortithyris thermae, nov. sp., by monotypy.

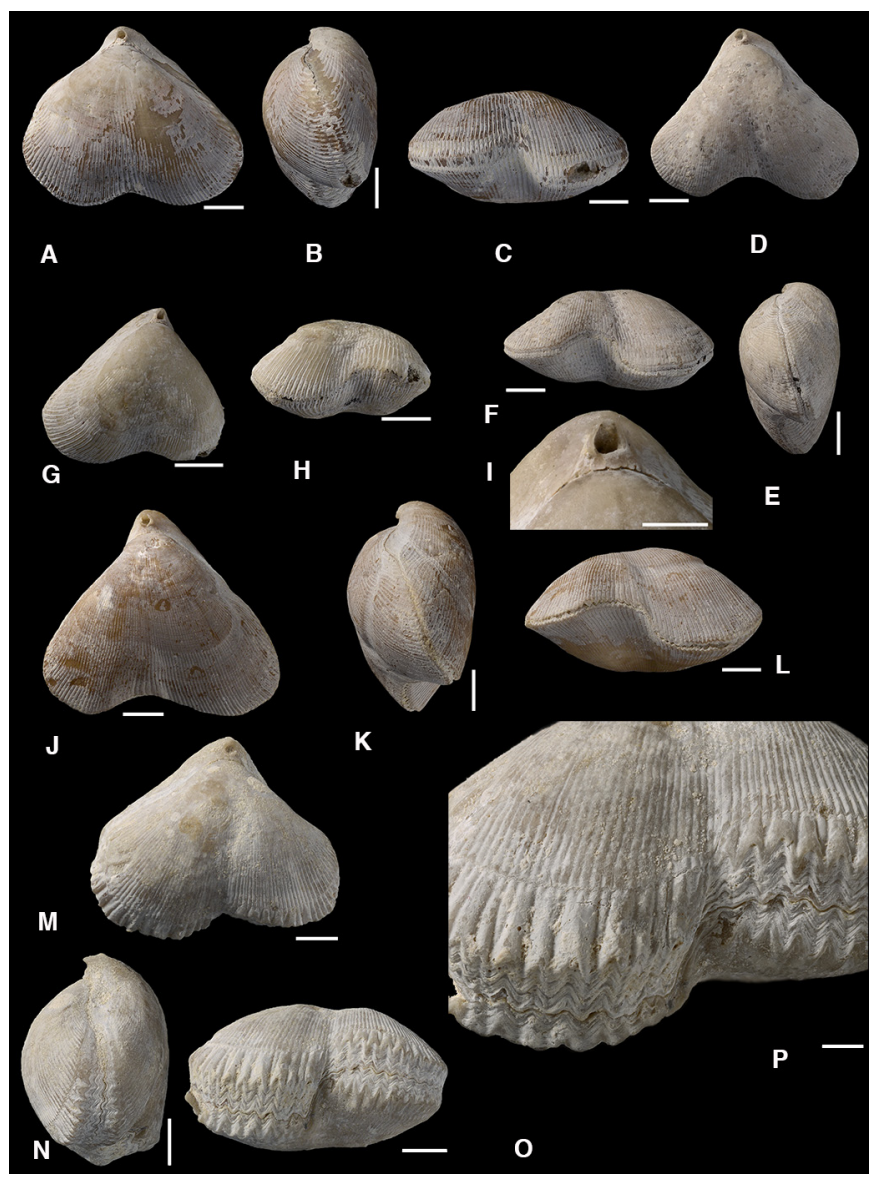

Fig. 10. Cyclothyris vesicularis (Coquand, 1860) from the Late Campanian of Aubeterre (Charente). A-C. Large specimen MNHN.F. A70583 (Péron coll.): dorsal view, profile revealing a depressed lateral commissure, and twisted anterior commissure. D-F. Specimen MNHN.F.A70584 (Péron coll.). G-I. Small adult specimen MNHN.F. S08809 (Péron coll.); close-up view of the ventral posterior shell with the foramen (I). J-L. Specimen SU.PAL.2018.0.55.22.1 (Arnaud coll.) from Puyvigier revealing some digitations of the costellae. M-P. Specimen SU.PAL.2018.0.55.22.2 of Puyvigier obviously with growing old signs (increasing thickness of the margins to the detriment of length and width), close-up view revealing that two/three costellae fused in one costa near the margins $(\mathrm{P})$. Scale bars $=5 \mathrm{~mm}$, except $(\mathrm{I}$ and $\mathrm{P})=2 \mathrm{~mm}$. Photographs: P. Loubry.

Etymology. - From the Latin contortus (contorted) in allusion to the shifted shape of the anterior margin.

Diagnosis. - Medium to large sized shell, anterior margin commonly asymmetrical; costae posteriorly fine and slightly sharp on the margins, medium-sized foramen, suberect beak.

Discussion. - Contortithyris nov. gen. is assigned to the Cyclothyridinae based on the asymmetrical anterior commissure and the deltidial plates forming short tube around foramen. It differs from Cyclothyris by its more massive globose shape, curved umbo, more rounded commissure and slightly finer costae, from Owenirhynchia by a wider size and thicker to globose shell, less high height of the twisted anterior margin, and from Beaussetithyris nov. gen. by the biconvex profile. It differs from all the other genera of the Cyclothyridinae by the asymmetrical anterior commissure. 


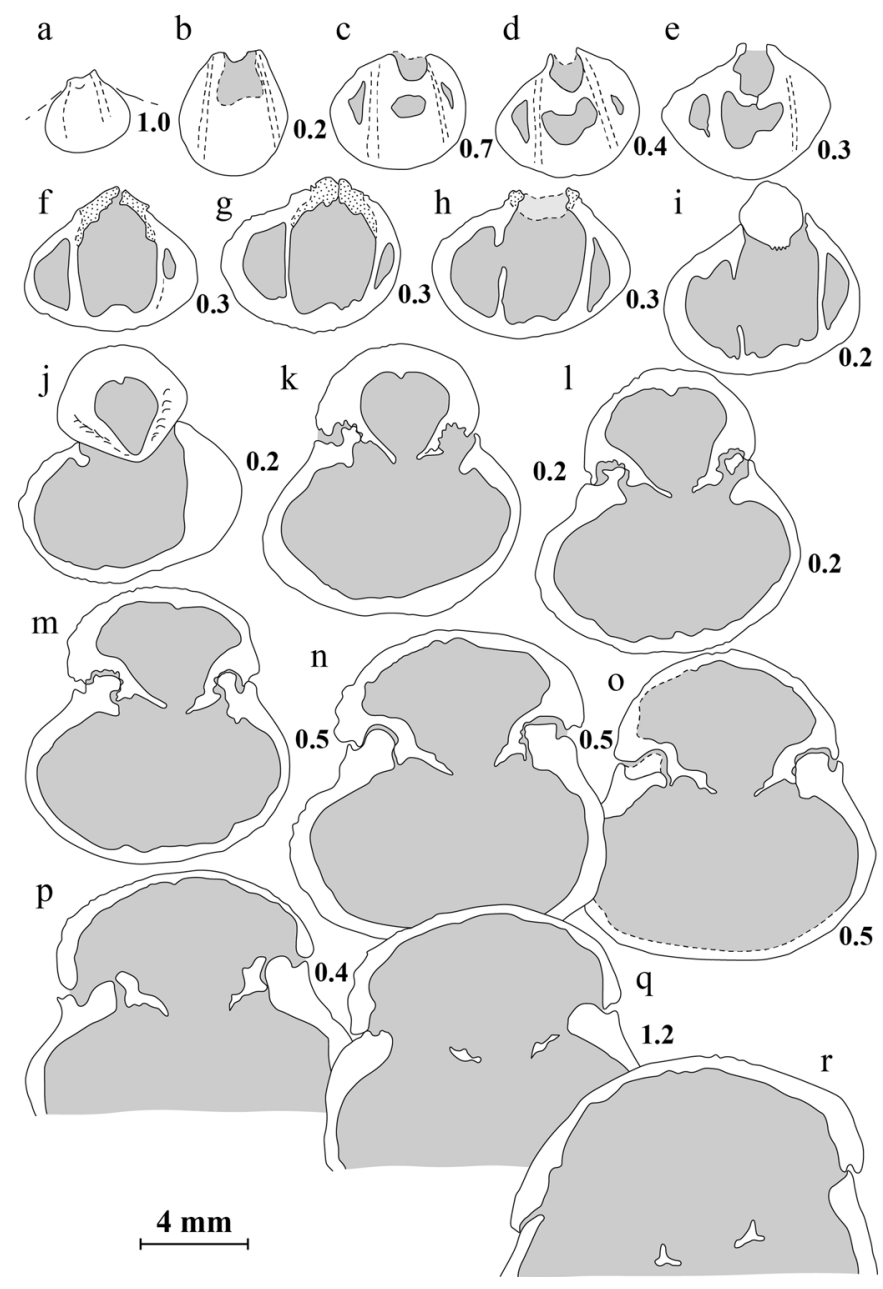

Fig. 11. Transverse serial sections in a shell MNHN.F.A70937 of Cyclothyris vesicularis (Coquand, 1860) from the Campanian (measurements: $22.3 \mathrm{~mm}$ in length, $28.0 \mathrm{~mm}$ in width and $17.6 \mathrm{~mm}$ in thickness). Internal characters from the posterior shell till the level of the crura. Line drawings: D. Gaspard.

\section{Contortithyris thermae nov. sp.}

Figures 12-14

Etymology. - The specific epithet alludes to the Antique thermal baths of the type locality Rennes-les-Bains.

Type material. - Holotype MNHN.F.A59945. 32 paratypes from Rennes-les-Bains (MNHN.F. A68144-A68146, A70586, A70587, A70639-A70642, A70873-A70885, A70887A70895, S09048), and three paratypes from Sougraigne (MNHN.F.A70643, A70644, A70597).

Type locality. - Rennes-les-Bains, Aude, Occitanie, France.

Type age. -Santonian (Marnes à Micraster Formation).

Diagnosis. - Medium to large size shell, biconvex, finely costate, posterior shell nearly smooth, medium round foramen, beak sharp, umbo suberect; anterior margin progressively to strongly asymmetrical with a pronounced high shift.

Description of external morphology (Figs. 12 and 13) Globose shells hardly wider than long (length: $12.4-31.5 \mathrm{~mm}$; width: $12.9-40.8 \mathrm{~mm}$ ) with a curved short and massive ventral umbo (erect in juveniles) ending by a dorsally pointed beak

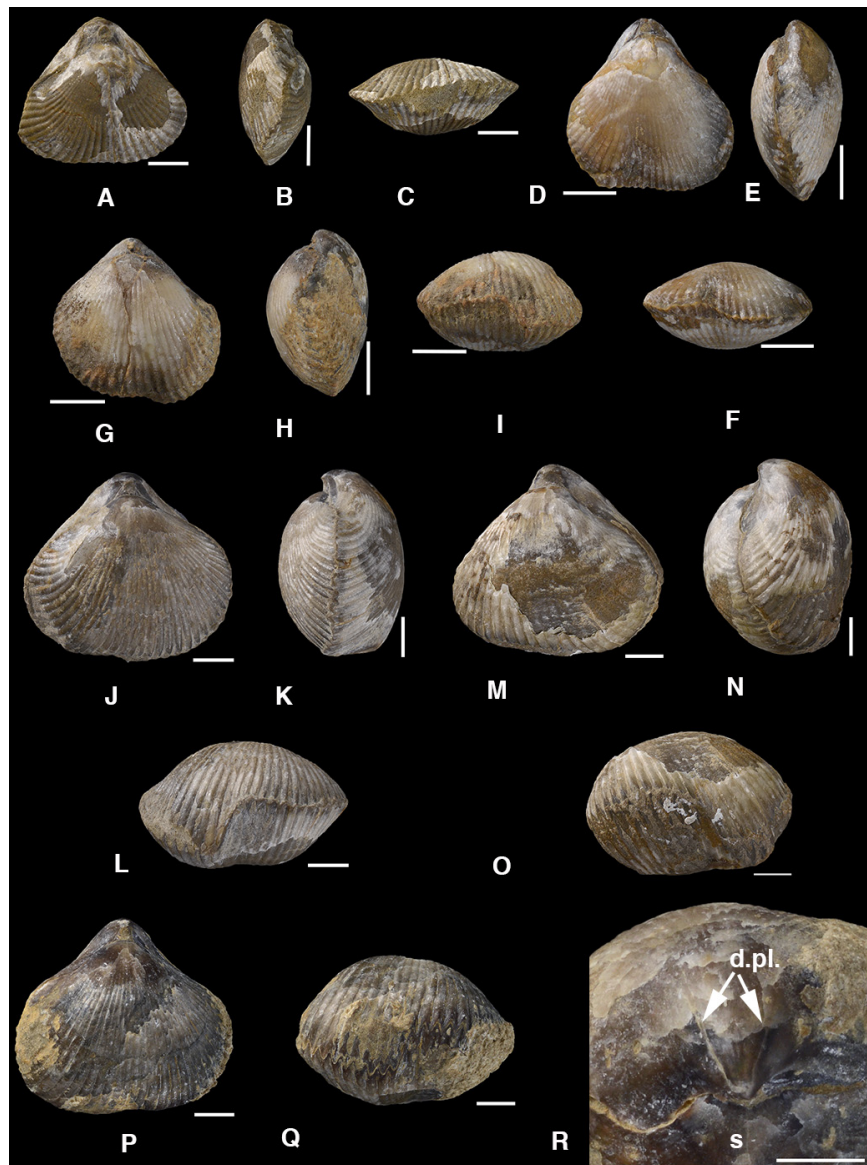

Fig. 12. Specimens of Contortithyris thermae nov. sp. from the Marnes à Micraster Formation, Early Santonian, Rennes-les-Bains (Aude, France). A-C. Juvenile specimen MNHN.F.A70586 with a rectimarginate anterior margin slightly distorted. D-F. Sub-adult specimen MNHN.F.A70587 with a beginning asymmetrical anterior margin. G-I. Young adult specimen MNHN.F.A70639 with an increasing asymmetry of the anterior margin. J-L. Adult specimen MNHN.F.A70640, with a pronounced left asymmetry (left side down) of the anterior margin. M-O. Adult specimen MNHN.F.A70641 with a pronounced right asymmetry (right side down) of the anterior margin. P-R. Adult specimen MNHN.F.A68144 with a worn posterior shell revealing traces of the dental plates (d. pl.) and dorsal septum (s) in a close-up view (R). Scale bars $=5 \mathrm{~mm}$. Photographs: P. Loubry.

accentuated by the lateral crests. The beak is not necessarily inclined on one side or the other (Figs. 12 and 13). The deltidial plates, $2.0-2.5 \mathrm{~mm}$ in height and $3-4 \mathrm{~mm}$ of basal width, are sometimes partly hidden, interrupted at their posterior part by the round/oval foramen of about $1.5-2.0 \mathrm{~mm}$ in diameter in adults. The foramen is lined by lateral expansions of the deltidial plates shaping an open tube. The dorso-lateral areas of the ventral beak are obviously smooth. The shells are ornamented by approximately 35-45 small acute angle costae (following the stage during ontogeny), not divided, of 1.0 $1.5 \mathrm{~mm}$ at the basal part, thin, even blurred at the posterior part of valves. The lateral margins are globally straight. The anterior margin tends progressively and slightly to be asymmetrical from the juveniles (Figs. 12C and 12F) to 


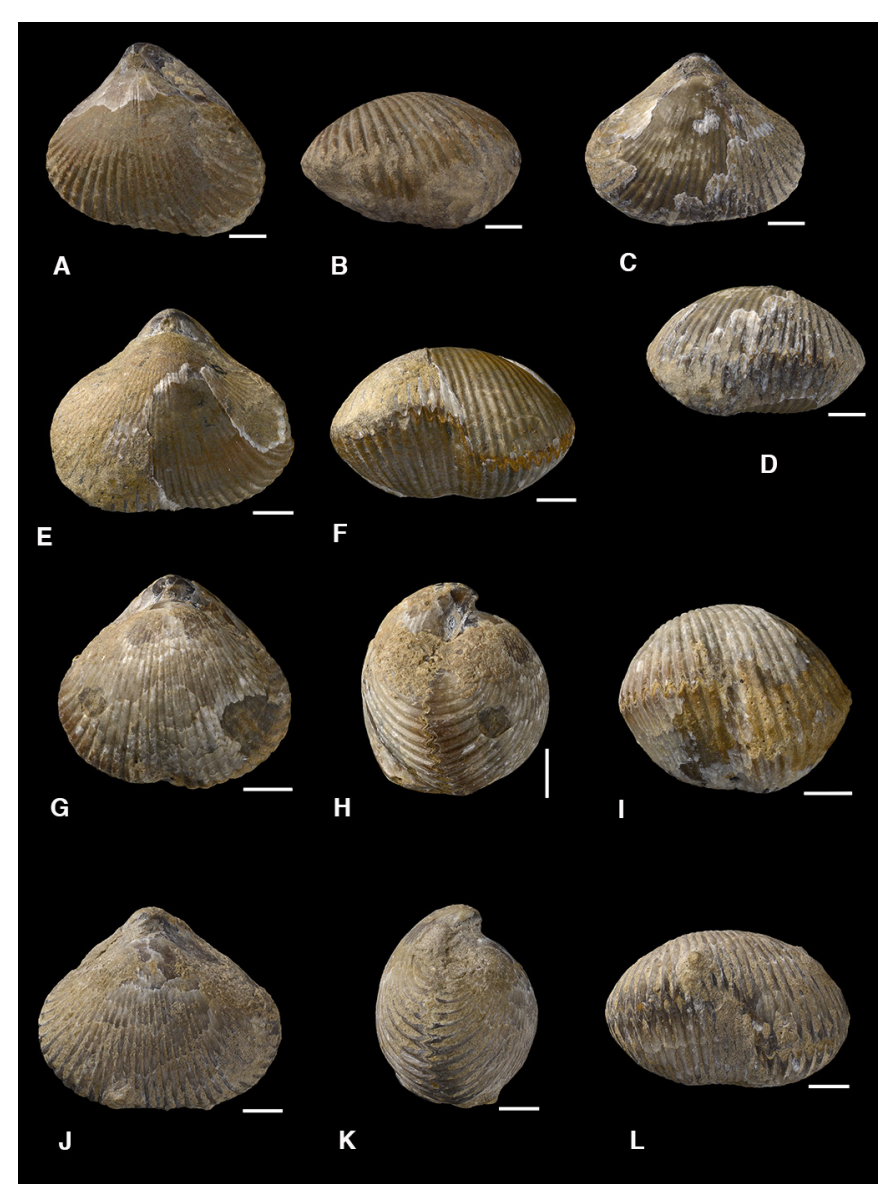

Fig. 13. Contortithyris thermae nov. sp. from the Marnes à Micraster Formation, Rennes-les-Bains, Aude, France (A-I) and from Sougraigne, Aude, France (J-L). A,B. Specimen MNHN.F. A68145. C,D. Specimen MNHN.F.A68146. E,F. Holotype MNHN. F.A59945 (specimen tentatively scanned using the AST-RX platform without positive result concerning the $3 \mathrm{D}$ modelling of the brachidium). G-I. Gibbous specimen MNHN.F.A70642. J-L. Specimen MNHN.F.A70643. Scale bars $=5 \mathrm{~mm}$. Photographs: P. Loubry.

markedly asymmetric in the adults, shifted with one side pulldown and the other one turned-up (Figs. 12I, 12L, 12O, 12Q, 13B, 13F, 13I, 13L). The deflection between the two parts is important; it follows a slight inclined line never reaching a vertical position (Figs. 12L and 13I). The specimens less than $20 \mathrm{~mm}$ in length, are flatter than the fully mature ones, and consequently present a smaller deflection of the lateral margin (Figs. 12B and 12E). In adults, the deflection of the anterior margin concerns 1 to 2, even 3 costae (Figs. 12I, 12L, 12O, 13B, 13F, 13I, 13L). Worn shells allow observing traces of the dental plates at the posterior ventral beak and of the dorsal septum (Fig. 12R).

Description of internal characters (Fig. 14) - Transverse serial sections in specimens MNHN.F.A70938 and A70939 reveal: strong dental plates, slightly inclined, becoming parallel and thinner anteriorly. The incidence of the curvature of the ventral umbo with its sharp beak is marked, as well as the lateral expansions of the deltidial plates on each side of the foramen (Figs. 14Ac-14Ae, 14Bb-14Bc). In specimens between 21 to $33 \mathrm{~mm}$ in length, the dental plates are half to one-third of the umbo shell thickness at $1.5-2.0 \mathrm{~mm}$ from the posterior part of the ventral valve (Figs. 14Aa-14Af, 14Ba$14 \mathrm{Be})$. The posterior dorsal valve reveals the beginning of the dental sockets (Figs. 14Af-14Ag, 14Be), deepening after (Figs. 14Ah-14Aj, 14Bf-14Bj), and a faint/moderate dorsal septum (Figs. 14Ai-14Am, 14Be-14Bm). The hinge plates are sub-horizontal. The hinge teeth are inserted faintly oblique in the crenulated dental sockets (Figs. $14 \mathrm{Ah}-14 \mathrm{Aj}, 14 \mathrm{Bg}-14 \mathrm{Bj}$ ). These teeth are constricted by the outer socket ridge and by the accessory inner socket ridge (Figs. $14 \mathrm{Ah}-14 \mathrm{Aj}, 14 \mathrm{Bh}-14 \mathrm{Bj}$ ). The crura are canaliform to subfalciform.

Microstructure. - Details of the crural bases and/or the relative shape of hinge teeth and dental sockets are presented in Appendix E.

Comments - The specimens from Sougraigne present the same proportions with those from Rennes-les-Bains, but some are wider than the standard and are thicker (Figs. 13J-13L). Some wider specimens from Sougraigne bear stronger costae (Fig. 13J). The peculiarity of all of these shells (both Rennesles-Bains and Sougraigne) is the high shifted right/left asymmetry of the anterior margin.

Beaussetithyris nov. gen.

Type species - Beaussetithyris asymmetrica nov. sp., by monotypy.

Etymology - From the locality of the type species, Le Beausset, Var, Provence-Alpes-Côte d'Azur, SE France.

Diagnosis. - Large shell, erected to suberected beak, costellate shell, costae sharp on the margins; foramen round to lightly oval, auriculate deltidial plates; anterior margin asymmetrical.

Discussion. - Beaussetithyris nov. gen. is assigned to the Cyclothyridinae based on the asymmetrical anterior commissure and the deltidial plates forming short tube around foramen. It differs from Cyclothyris by its dorsibiconvex shell, often more massive, from Owenirhynchia by the size and the thickness of the shell, and from Contortithyris by slightly greater size, obvious wider foramen and stronger costae.

Beaussetithyris asymmetrica nov. sp.

Figures 15-17

Etymology. - The specific epithet alludes to the asymmetrical shape of the anterior commissure.

Type material - Holotype MNHN.F.A67492. Seven paratypes MNHN.F.A59946, A67493, A67481-A67485 from Le Beausset; one paratype MNHN.F.A26502 from La Cadière; five paratypes MNHN.F.A59948, MNHN.A70117, A70118, A70811, A70886 from Les Martigues. All are from Var department, SE France.

Type locality. - Le Beausset, Var, SE France.

Type age. - Early Santonian.

Additional material. - One specimen MNHN.F.S09235 (coll. Péron) from Le Castellet; two specimens MNHN.F. A70798, A70799 (d'Orbigny coll.) from La Cadière; two specimens MNHN.F.A61729, A70812 (d'Orbigny coll.) from Le Beausset; two specimens MNHN.F. A59947, A70645 from Les Martigues.

Diagnosis. - Medium to large shells, dorsibiconvex, conjunct deltidial plates, auriculate laterally, lateral margins slightly inclined ventrally, asymmetric anterior margin with a shift evenly high. 

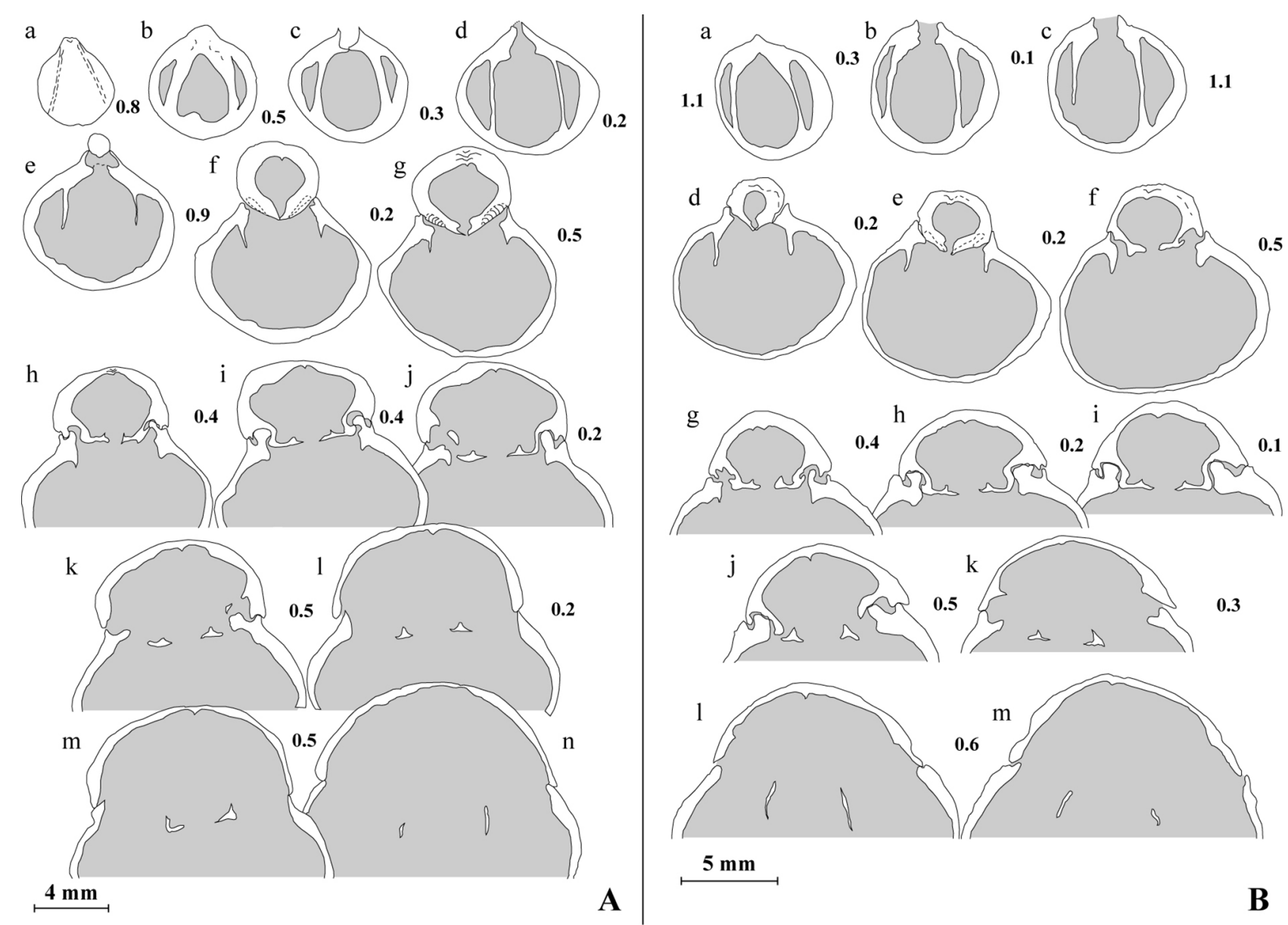

Fig. 14. Transverse serial sections in Contortithyris thermae nov. sp. from Rennes-les-Bains (A, MNHN.F.A70938) and Sougraigne (B, MNHN. F.A70939), from the posterior shell till the level of the crura, to locate the internal characters. Line drawings: D. Gaspard.

Description of external morphology. - (Figs. 15 and 16) Right and left asymmetric adult shells are mainly massive, dorsibiconvex, with a sub-erect ventral umbo, rarely ending by a pointed beak. The adult shells are 21.7 to $32.9 \mathrm{~mm}$ in length, 21.1 to $37.8 \mathrm{~mm}$ in width and 14.9 to $27 \mathrm{~mm}$ in thickness. The dorsal surfaces of the beak are smooth. The rounded foramen encroaches on the posterior part of the deltidial plates forming a short tube. The foramen is about $1.5 \mathrm{~mm}$ in diameter (even wider). The shells are ornamented by 29 to 36 , even 39 costae. Few juvenile specimens and/or preadults (about $19.3 \mathrm{~mm}$ in length) show proofs of a beginning asymmetry with fine costae $(1 \mathrm{~mm}$ at the margin). Some specimens reveal a displacement of the monoplication towards one side (Fig. 16G) rather than a displacement of the asymmetry as illustrated in Figure 16J.

Description of internal characters. - (Fig. 17) Transverse serial sections of the asymmetrical specimens from Le Beausset (Fig. 17A) and Les Martigues (Fig. 17C), and virtual transverse views from the scanned specimen MNHN.F. A26502 (La Cadière, Appendix D) reveal: globally parallel dental plates (17Ae-17Ah, $17 \mathrm{Cb}-17 \mathrm{Cf})$, lateral expansions of the conjunct deltidial plates, an auriculate foramen, sometimes a more curved dorsal umbo (Figs. 17Ag-17Ai, 17Cf), a short dorsal septum becoming faintly higher anteriorly
(Figs. 17Ak-17Au) compared to the more discreet one in les Martigues (Figs. $17 \mathrm{Cf}-17 \mathrm{Cm}$ ), and hinge plates slightly undulating ventrally, then slightly oblique towards the ventral valve. The crura are raduliform (Figs. $17 \mathrm{Ar}-17 \mathrm{At}, 17 \mathrm{Cl}$ 17Co). A sub-asymmetrical shell from Le Beausset is illustrated for comparison (Fig. 17B).

Microstructural details. - Details of the crural bases and/or the relative shape of hinge teeth, dental sockets, and dorsal septum are presented in Appendix E.

Comments. - Some specimens herein identified as Beaussetithyris asymmetrica present subasymmetrical shells characterized by an uncommon shifted anterior margin with one side obviously longer than the other one (Figs. 16H-16J). These shells are more massive than the type material. They show a more erect umbo, and a wider foramen. They are biconvex to dorsibiconvex (length: $24.1-31.7 \mathrm{~mm}$; width: 27.7-35.9; thickness: $19.4-21.7 \mathrm{~mm}$ ). In adult specimens, the foramen is round $(1.25-1.75 \mathrm{~mm}$ in diameter). They present longer dental plates (Figs. 17Bd-17Bq), an auriculate foramen (Figs. 17Bb-17Bg), an important dorsal umbo with an important dorsal median septum that has no equivalent in the shells previously described (Figs. 17Bh-17Bs), hidden and narrow posterior dental sockets (Figs. 17Bl-17Bm), thick 


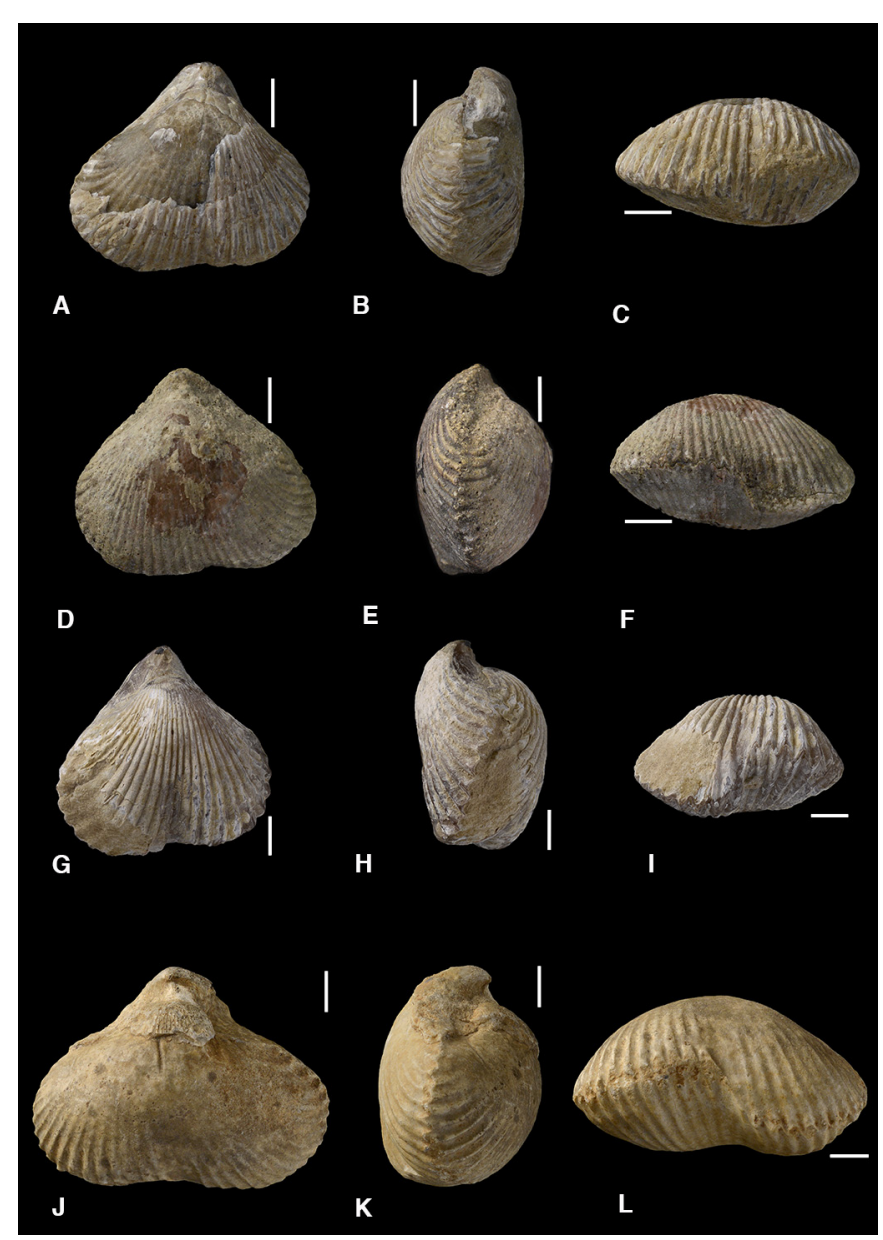

Fig. 15. Beaussetithyris asymmetrica nov. sp. from the Early Santonian of Basse-Provence, SE France. A-C. Holotype MNHN. F.A67492 (Péron coll.) from Le Beausset, Var. D-F. Paratype MNHN. F.A67493 (Péron coll.) from Le Beausset. G-I. Paratype MNHN.F. A.59946 (Péron coll.) from Le Beausset. J-L. Paratype MNHN.F. A26502 (d'Orbigny coll.) from La Cadière (see video online, Appendix D). Scale bars $=5 \mathrm{~mm}$. Photographs: P. Loubry.

hinge teeth inserted more vertically in the dental sockets than in the previous (Figs. 17Bn-17Bq), small lateral accessory teeth and dental sockets (Figs. 17Bp-17Bs) and swollen hinge plates posteriorly then forming an open angle towards the dorsal floor, subcanaliform to raduliform crura (Figs. 17Bu17By).

Comparisons between the two sets of sections (Figs. 17A17C) reveal differences between the asymmetrical type specimens and the subasymmetrical ones. Only new additional specimens will allow to precise if the observed differences are linked to a great variability in Beaussetithyris asymmetrica or if it is necessary to distinguish two different taxa.

Owenirhynchia Calzada in Calzada and Pocovi, 1980

Type species. - Owenirhynchia rubra Calzada in Calzada and Pocovi, 1980

Owenirhynchia sp.

Figures 18 and 19

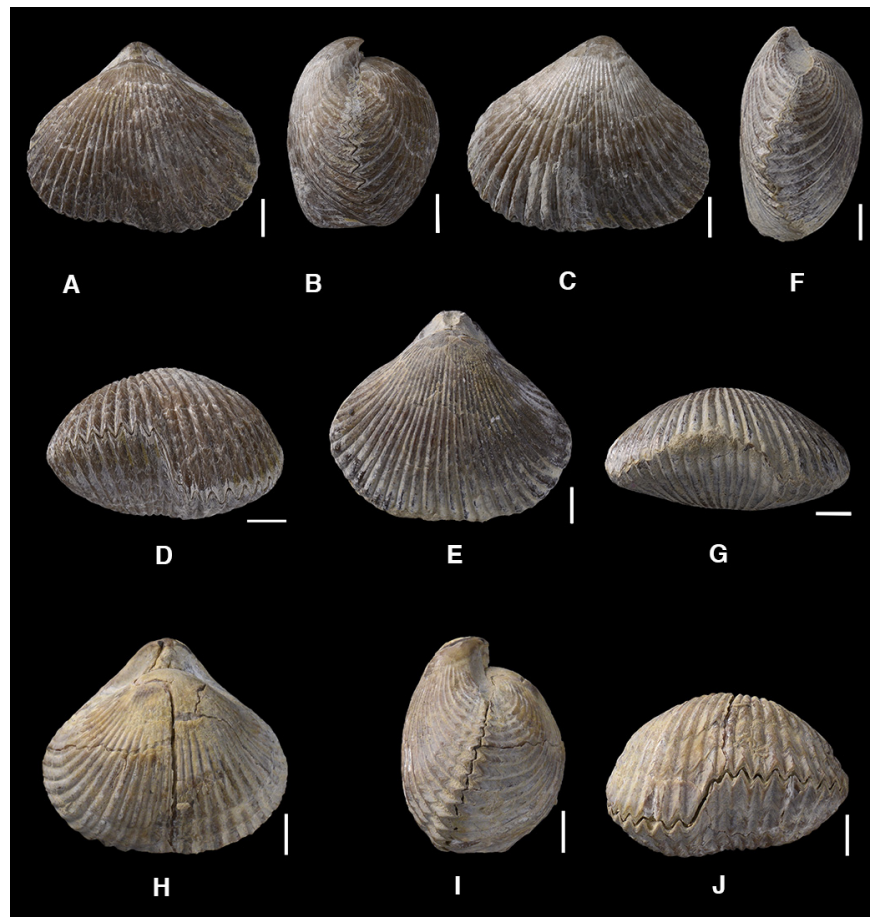

Fig. 16. Beaussetithyris asymmetrica nov. sp. from the Early Santonian of Les Martigues (Basse-Provence, SE France). A-D. Paratype MNHN.F.A59948, dorsal (A), lateral (B), ventral (C) views; note the step-like asymmetrical anterior commissure (D). E-G. Adult specimen MNHN.F.A59947 with a shape intermediate between monoplicate anterior margin and translatory motion of the anterior margin on one side (sub-asymmetrical shape). H-J. Adult specimen MNHN.F.A70645 with a strong shifted anterior margin but with a slight translatory motion of the anterior margin. Scale bars $=5 \mathrm{~mm}$. Photographs: P. Loubry.

Examined material. - Specimens sampled from the Coniacian-Santonian (Nidáguila Formation) of the North Castilian Platform (Villamartin section), among them two MNHN.F. A70942, A70943 were used for transverse serial sections.

Description of external morphology (Fig. 18) - Medium sized subtriangular, equibiconvex multicostate shell, wider than long with a sub-erect ventral beak, deltidial plates shaping the typical short tube of the Cyclothyridinae around the subrounded foramen (diameter: often $1 \mathrm{~mm}$, even more); slight asymmetry of the anterior margin (Figs. 18B and 18D).

Description of internal characters. (Fig. 19) - Sets of transverse serial sections of specimens from different levels reveal: joined wide deltidial plates which lateral expansions shape a tube around the foramen (Figs. 19Aa-19Ac, 19Ba, 19Bb), dental plates sub-parallel becoming slightly divergent (Figs. 19Aa-19Ae, 19Ba-19Be), supporting deeply inserted subquadrate hinge teeth, and consequently wide and deep dental sockets (Figs. 19Ad-19Ag, 19Bf-19Bh), hinge plates ventrally concave, crura canaliform to distally concave raduliform (Figs. 19Ag-19Ai, 19Bf-19Bh), reduced dorsal septum. 

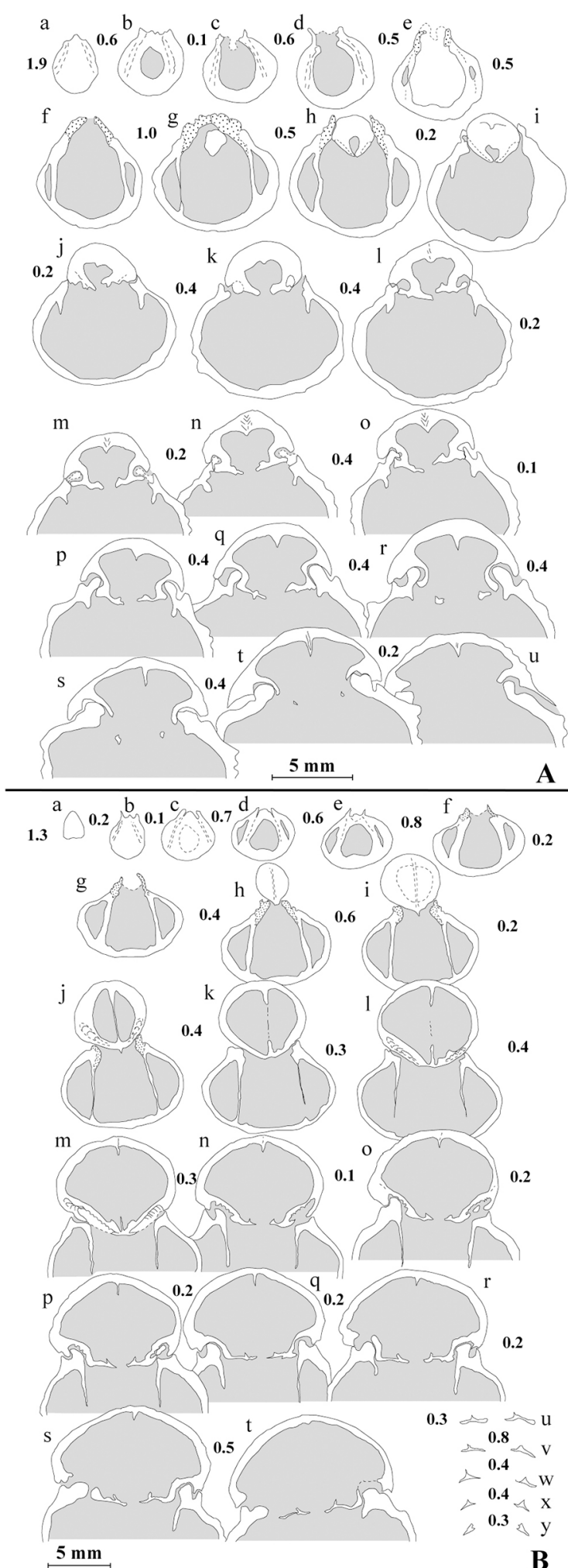

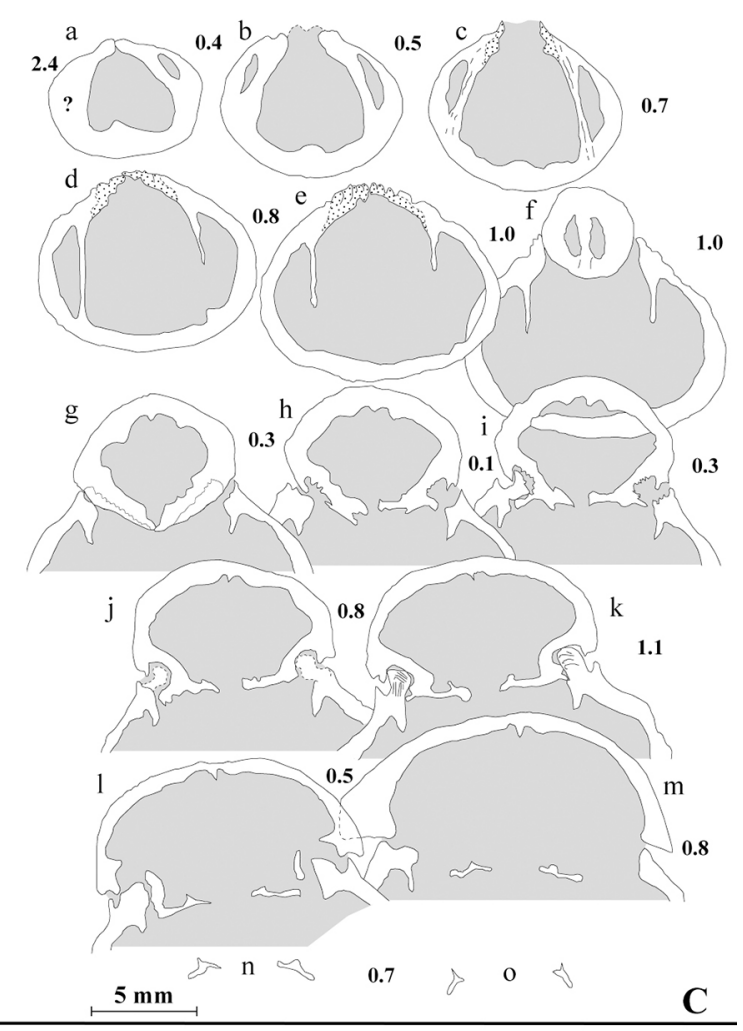

Fig. 17. Transverse serial sections in three shells of Beaussetithyris assymmetrica nov. sp. from Basse-Provence, France. A. Specimen MNHN.F.A70940 from Le Beausset (length: 24.1, width: 23.1, thickness: $15.3 \mathrm{~mm}$ ). B. Specimen MNHN.F.S09134 from Le Beausset, revealing a translation of the sub-asymmetrical shape of the anterior commissure. C. Specimen MNHN.F.A70941 from Les Martigues (length: 33.1, width: 31.8, thickness: $22.9 \mathrm{~mm}$ ). Line drawings: D. Gaspard. 


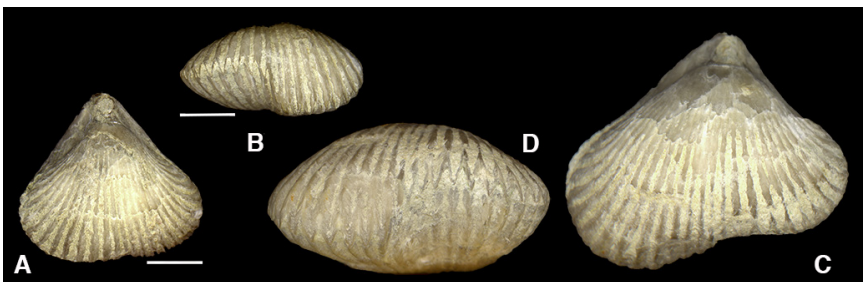

Fig. 18. Owenirhynchia sp. from the Nidàguila Formation, Villamartin, Spain. A,B. Specimen MNHN.F.A70942. C,D. Specimen MNHN.F.A70943. Photographs: University Paris 11.

Comments. - The genus Owenirhynchia interpreted by Manceñido et al. (2002: 1334), as a possible subgenus of Cyclothyris or as a subjective synonym of this genus requires the observation of additional specimens for a deeper revision.

\section{Discussion}

Asymmetry is an important and widespread trait, having evolved numerous times in many invertebrate and vertebrate organisms and at many levels of organisation ranging from individual cells, through organs (e.g., brain, heart) to entire body-shapes. Geneticists try to explain this reality highlighting that the asymmetrical structure of the proteins that composed the living species are responsible of the observed asymmetry (see Flamant, 2016). Stern (2002) explained that the asymmetries between the right- and left-hand sides of the bodies are initiated at an early stage of development. In their approach of asymmetry at the level of the biomineralization process, Addadi and Weiner (2001) exposed that "understanding the formation of asymmetrical shapes during the growth of symmetrical structures is the first step towards understanding asymmetry in biology". They reported that chiral shapes in biologically formed molecules lead to crystals involved in the formation of part of skeleton/exoskeleton of living organisms including vertebrates as well as invertebrates. Living organisms as well as fossils are concerned.

Among the invertebrates, brachiopods are concerned by asymmetry in their exoskeleton (shells). Among rhynchonelliform brachiopods, only rhynchonellids are affected by asymmetry. No modern example has been identified in the current state of our knowledge. Asymmetry is confined to rhynchonellids at certain times during evolution (Fürsich and Palmer, 1984). This observation goes against an ecophenotypical origin which logically should concern all groups of brachiopods at all times. Therefore, this rather suggests another origin, genetic, in some groups (i.e., in some rhynchonellids) as illustrated here. Several outstanding examples were found during the Mesozoic (Jurassic-Late Cretaceous: Owen, 1962; Popiel-Barczyk, 1977; Fürsich and Palmer, 1984; Gaspard, 1985, 1991; Muñoz, 1985, 1994; Motchurova-Dekova, 1995 among others).

Since then and recently, several authors (Afanasjeva, 2014; Berrocal-Casero et al., 2017; Schrøeder et al., 2017) proposed new cases of brachiopods showing asymmetry or ecophenotypical asymmetry. Careful examination of these three publications lead us to identify a confusion between asymmetry and dissymmetry. Most of the discussed modifications in the symmetry of the brachiopod shells are linked to palaeoenvironmental conditions and thus are of ecophenotypical origins. They correspond to cases of dissymmetry (see precisions in the present introduction). For instance, BerrocalCasero et al. (2017; see their Fig. 13) hypothesized that the "functional meaning asymmetry" of rhynchonellid brachiopods from Northern Spain may be interpreted to an adaptation to sinking in soft substrates taking place as a response to changes in palaeoenvironmental conditions, and thus proposed semi-buried specimens. We remark that their hypothesis of semi-buried specimens staying till the adult stage in a position on one side or the other is not relevant. Such a position would lead quickly to the infilling of the shell by the sediment and consequently to the inefficiency of the lophophore or the ability to feed. In conclusion, we note that Berrocal-Casero et al. (2017) presented true asymmetrical specimens and true dissymmetrical specimens but the origin of the modification of the shifted commissures are different for us: genetically based in the first case and linked to the palaeoenvironments in the second one. We remark that it is also possible to observed true asymmetrical specimens affected by dissymmetry (Figs. 2J, 2K, 4M-4O).

In the present study, we identify asymmetry in four rhynchonellid genera (Cyclothyris, Contortithyris, Beaussetithyris, Owenirhynchia) at level of the anterior commissure showing a left-up/right-down shift, or the reverse. The observation of the shifted anterior commissure with approximately $50 \%$ of right-asymmetrical specimens and $50 \%$ of leftasymmetrical ones in Cyclothyris globata, and C. grimargina (see Tabs. 1 and 2) militates in favour of a genetic origin rather than an ecophenotypical expression. We point out that in Cyclothyris difformis, C. grimargina and Contortithyris thermae, this asymmetrical expression is not visible at juvenile stage and does not hit the internal hard parts of the shell, i.e., the crura.

Flamant (2016) explained that some genes (hidden or particularly associated) could be at the origin of asymmetry in different organisms. In our study, the origin of asymmetry is difficult to understand due to the lack of extant asymmetrical brachiopods. This prevents genetic observations and, as a matter of fact unable us to achieve a conclusion on the probability of a modification or the "freezing" of a morphogen. Following Fürsich and Palmer (1984), our feeling in the present cases is that the expression of asymmetry, genetically based, could emerge periodically in the course of evolution of brachiopods.

\section{Supplementary Material}

Appendix A. Video of the virtual transverse serial sections of specimen MNHN.F.A59944 of Cyclothyris difformis. (Patricia Wils, UMS 2700).

Appendix B. Video of the virtual longitudinal serial sections of the same specimen MNHN.F.A59944 of Cyclothyris difformis. (Patricia Wils, UMS 2700).

Appendix C. Virtual transverse serial sections of specimen MNHN.F.A59944 of Cyclothyris difformis. The numbered views correspond to a selection of virtual sections among the set of images. 

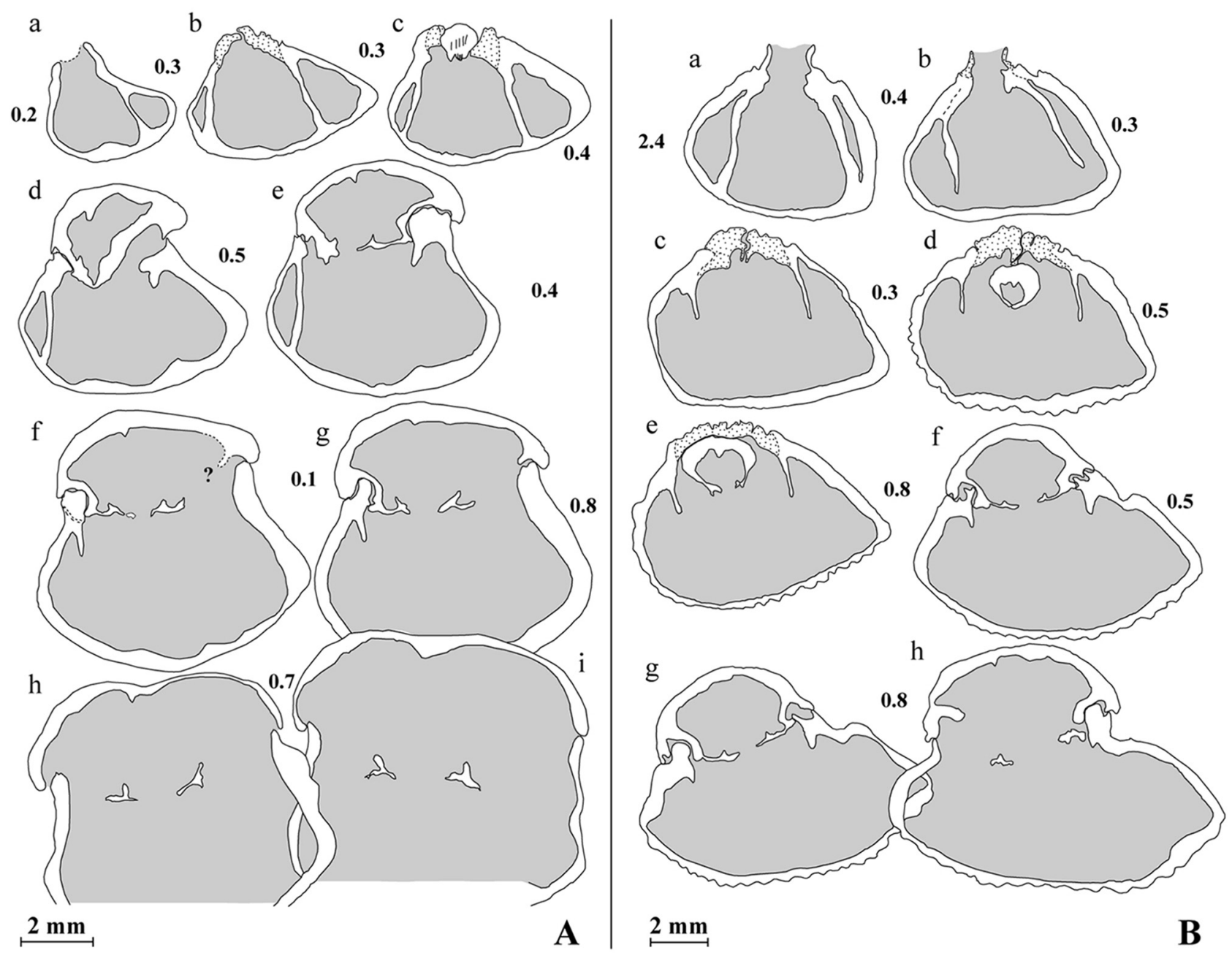

$2 \mathbf{m m}$

B

Fig. 19. Transverse serial sections from the posterior shell of specimens of Owenirhynchia sp. from two different layers: 127 (A, MNHN.F. A70942) and 128 (B, MNHN.F.A70943) of the Nidàguila Formation at Villamartin (Spain). Line drawings: D. Gaspard.

Appendix D. Video of the virtual transverse serial sections of paratype MNHN.F.A26502 of Beaussetithyris asymmetrica from La Cadière. (Patricia Wils, UMS 2700).

Appendix E. SEM views of selected transverse sections of Senonian asymmetrical rhynchonellid shells. A,B. Beaussetithyris asymmetrica nov. sp. from Les Martigues: details of the articulation in section (dental plates (d. pl.), hinge plates (h.pl.), teeth (t) and crus (cr) in (A), the arrowhead indicates the location of the close-up view of the crus (B). C,D. Beaussetithyris asymmetrica nov. sp. from Le Beausset: details of the articulation in a section, note the dental sockets (d.s), and close-up view in the right side (D) shown by the arrowhead. E-G. Contortithyris thermae nov. sp. from Sougraigne, details of the shell articulation in a section; close-up view of the septum (s) in a partly recrystallized shell $(\mathrm{G})$.

The Supplementary Material is available at http://www.bsgf.fr/ 10.1051/bsgf/2019016/olm.

\section{Taxa registration:}

Beaussetithyris : urn:1sid:zoobank.org:act:4E5DD696-F0A04B2F-834B-BA7DF0635E95

Beaussetithyris asymmetrica : urn:1sid:zoobank.org:act: E057611E-0F7F-437F-925C-3F50B66D139E

Contortithyris : urn:lsid:zoobank.org:act:AB1114CE-1DA04336-902E-40C1508EA90A

Contortithyris thermae : urn:lsid:zoobank.org:act:814458A79B64-4F0E-ABE3-18E6B26C438C

Cyclothyris grimargina : urn:1sid:zoobank.org:act:5E005E69727F-4A67-8BB3-CDDBF3B3BD1A

Acknowledgements. The authors gratefully acknowledge $\mathrm{G}$. Bailly (Musée d'Angoulême), M. Bilotte (Univ. Paul Sabatier), J.F. Babinot $\dagger \&$ G. Tronchetti $\dagger$ and M. Floquet (Univ. AixMarseille 1), D. Grosheny (Univ. Lorraine), D. Néraudeau(Univ. Rennes 1), L. Villier (Sorbonne-Université) for specimens; D. Pajaud $\dagger$ and S. Jouve (Sorbonne-Université) for the loan of specimens from Arnaud collection, and Palotás Klára, Makádi 
László, and Zoltán Lantos of the Mining and Geological Survey of Hungary who provided and authorized the use of digital images of C. vesicularis (Coquand coll.). Thanks are also due to Ph. Loubry (CR2P, UMR 7207 CNRS-MNHN, SorbonneUniversité) for help in the studio imagery, A. Lethiers, CR2P, UMR 7207 CNRS, Sorbonne-Universté, for help in achievement of drawings, M. Bellato and P. Wils (AST-RX platform UMS 2700, CNRS-MNHN, Sorbonne-Université) for help respectively for scanning the specimens and video creation. J-M. Pacaud (MNHN) is also thanked for collection numbers. We are grateful to B. Radulović for her review.

\section{References}

Addadi L, Weiner S. 2001. Crystals, asymmetry and life. Nature 411: 753-755.

Afanasjeva GA. 2014. Asymmetry in brachiopods. Paleontological Journal 48: 1207-1214.

Ager DV. 1965. The adaptation of Mesozoic brachiopods to different environments. Palaeogeography, Palaeoclimatology, Palaeoecology 1: $143-172$.

Archiac (d') JA. 1854. Coupe géologique des environs des Bains-deRennes (Aude), suivie de la description de quelques fossiles de cette localité. Bulletin de la Société géologique de France 2(11): 185-229.

Arnaud H. 1877. Le terrain Crétacé du Sud-Ouest de la France. Mémoire de la Société géologique de France Série 2, 10(4): 1-110.

Asgaard U. 1968. Brachiopod palaeoecology in Middle Danian limestones at Fakse, Denmark. Lethaia 1: 103-121.

Asgaard U, Bromley RG. 1991. Population dynamics and autecology of "Rhynchonella" triangularis, a Late Cretaceous rocky coast brachiopod. In: MacKinnon D, Lee DE, Campbell JD, eds. Brachiopods through time. Proceedings of the 2nd International Brachiopod Congress, Dunedin, New Zealand, 1990. Rotterdam, pp. 247-252.

Babinot JF. 1980. Les Ostracodes du Crétacé Supérieur de Provence. Systématique. Biostratigraphie. Paléoécologie. Paléogéographie. Thèse de l'Université de Provence 10, T1: 1-294 p; T.2: 295$634+\mathrm{B} 1-\mathrm{B} 34$.

Babinot JF, Philip J, Tronchetti G. 1984. Basse Provence. In : Philip J, ed. Synthèse du Sud-Est de la France. Chap. 7 : Crétacé Supérieur. Mémoire du BRGM 125: 359-363.

Basse E. 1939. Sur quelques Mollusques crétacés des Corbières méridionales. Bulletin de la Société géologique de France Série 5, 9: 35-57.

Berrocal-Casero M, Barroso-Barcenilla F, García Joral F, Segura M. 2017. Functional meaning of asymmetrical commissures in Coniacian (Upper Cretaceous) rhynchonellide brachiopods from Northern Spain. Cretaceous Research 79: 77-90.

Bilotte M, Freytet P. 1984. Le Crétacé supérieur marin des Corbières orientales (30 avr. 1982). Excursion du groupe Français du Crétacé: $1-59$.

Buckmann SS. 1906. Brachiopod nomenclature. Annals and Magazine of Natural History, London 18(7): 32-327.

Calzada S, Pocovi A. 1980. Braquipòdos senonienses de la sierra de Mont-Roig (prepirineo de Lérida). Bolletin de la Real Sociedad Espanola de Historia Natural (Geologica) 78: 5-19.

Clerc M, Fabre J. 1918. Catalogue illustré de la collection Lamarck, Part I (1-117 pls). Genève: Georg \& Cie Libraires.

Coquand H. 1860. Synopsis des animaux et des végétaux fossiles observés dans la formation secondaire de la Charente, de la Charente-Inférieure et de la Dordogne. Marseille : Barlatier-Feissat et Demonchy.
Coquand H. 1862. Géologie et paléontologie de la région sud de la province de Constantine. Mémoires de la Société d'Émulation de la Provence 2: 1-305.

Duméril AMC. 1805. Zoologie analytique ou méthode naturelle de classification des animaux. Paris : Allais.

Fage G. 1934. Les rhynchonelles du Crétacé Supérieur des Charentes. Bulletin de la Société géologique de France Série 5, 4: 433-441.

Flamant F. 2016. La science insolite de l'asymétrie. Paris : Éditions du Seuil.

Floquet M. 1978. La sédimentation carbonatée au Crétacé Supérieur dans la Vieille Castille (Espagne): exemple d'évolution sur une plate-forme stable. In: $\sigma^{e}$ Réunion Annuelle des Sciences de la Terre, Orsay, SGF, 165 p.

Floquet M. 1991. La plateforme Nord-Castillane au Crétacé Supérieur (Espagne). Arrière-pays ibérique de la marge passive bascocantabrique. Sédimentation et Vie. Mémoires Géologiques de l'Université de Dijon 14: 1-925.

Floquet M, Alonso A, Meléndez A. 1982. El Cretácico superior. Cameros-Castilla. In: García A, ed. El Cretácico de España. Universidad Complutense de Madrid, pp. 387-456.

Fürsich FT, Palmer T. 1984. Commissural asymmetry in brachiopods. Lethaia 17: 251-265.

Gaspard D. 1985. Commentaires sur les Brachiopodes de l'Autoroute A10. Cretaceous Research 6: 113-115.

Gaspard D. 1991. Les cas de non-symétrie chez les rhynchonelles. Quelles(s) signification(s)? Geobios MS 13: 33-44.

Gaspard D. 2010. Diversité observée chez les Rhynchonelles asymétriques, brachiopodes du Coniacien-Santonien des plateformes carbonatées: Nord Castillane (N. Espagne), Mouthoumet et Provence (SE. France). In: Strati 2010, 4th French Congress on Stratigraphy, UPMC-Paris 6, August 30-September 2, Abstract Vol.

Gaspard D. 2013. X-ray computed tomography: A promising tool to investigate the Brachiopod shell interior. Effects on 3D modelling and taxonomy. Compte Rendus Palevol 13: 149-158.

Gaspard D. 2014. Noteworthy brachiopods of the Cenomanian stratotype: A synthesis of the biochronological, palaeoenvironmental and palaeoecological implications. Geobios 47: 347-370.

Gaspard D. 2017. La dérangeante question de la commissure frontale distordue de rhynchonelles (Brachiopodes) du Crétacé Supérieur en Europe Occidentale. Asymétrie vs dissymétrie. In: Congrès APF, Dijon, Mars 2017. Oral presentation. Abstract Volume: 11.

Gaspard D, Odin GS. 2001. Brachiopodes du Campanien-Maastrichtien à Tercis-les-Bains (Landes, France). In: Odin GS, ed. The Campanian-Maastrichtian stage boundary. Characterisation at Tercis-les-Bains (France) and correlation with Europe and other continents. Elsevier. Developments in Palaeontology and Stratigraphy 19 , pp. $423-436$.

Grosheny D. 1986. Paléoécologie et dynamique sédimentaire d'un modèle de banc à Rudistes : exemple du Santonien de la Cadière (Sud-Est France). Tome 1: Stratigraphie. Paléoenvironnements. Diagenèse. Micropaléontologie : $1-500 \mathrm{p}$; Tome 2 : Atlas. Thèse de Doctorat de 1'Université de Provence (Aix-Marseille 1). [unpublished].

Hancock J. 1991. Ammonite time scales for the Cretaceous system. Cretaceous Research 12: 259-291.

Kennedy WJ, Bilotte M, Melchior P. 1995. Ammonite faunas, biostratigraphy and sequence stratigraphy of the ConiacianSantonian of the Corbières (NE Pyrénées). Bulletin des Centres de Recherche et Exploration-Production d'Elf-Aquitaine 19: 377-499.

Kuhn O. 1949. Lehrbuch der Paläozoologie. Stuttgart: E. Schweizerbart'sche Verlagbuchhandlung (Erwin Nägele).

Lamarck JB. 1819. Histoire naturelle des animaux sans vertèbres, 6 . Paris : Dufart. 
Lamolda MA, Pons JM, Dhondt AV. 2002. Meeting on the Coniacian-Santonian Boundary. Bilbao, 14-17 September, 2002- IUGS. ICS- Subcommission on Cretaceous Stratigraphy. Santonian Working Group \& Instituto Geológico y Minero de España (I.G.M.E. Geological Survey of Spain. Abstract volume.

Makridin VP. 1955. Nekotorye Ûrskie rinhonellidy Evropejskoj časti SSSR. Zapiski Geologičeskogo Fakulteta Har'kovskogo Universiteta, 12: 81-91.

Manceñido M, Owen EF, Dong-Li S, Dagys AS. 2002. Hemithiridoidea. In: Kaesler RL, ed. Treatise on Invertebrate Paleontology (Part H), Brachiopoda Revised Vol.4. Lawrence, Kansas: The Geological Society of America and the University of Kansas, pp. H1326-H1369.

M'Coy F. 1844. Synopsis of the characters of the Carboniferous limestone fossils of Ireland. Dublin: University Press.

Motchurova-Dekova N. 1994. New data about the evolution and phylogenetic relations of brachiopod families Basiliolidae and Cyclothyrididae on the basis of Late Cretaceous rhynchonellids from Bulgaria. Geologica Balcanica 24: 21-29.

Motchurova-Dekova N. 1995. Late Cretaceous Rhynchonellida (Brachiopoda) from Bulgaria. I. Genus Cyclothyris McCoy. Geologica Balcanica 25: 35-74.

Muñoz J. 1985. Braquiopodos del Cretacico Superior de los alrededores de St. Corneli (Prov. Lleida). Publicaciones de Geologia 21: 1-125.

Muñoz J. 1994. Estudio paleontológico y biostratigráfico de los braquiòpodos del Cretàcico Superior del Pirineo catalàn; Publications de la Universidat Autònoma de Barcelona. Tesina doctoral, Bellatera (Edito microfotographica), pp. 1-377.

Néraudeau D, Vullo R, Mazan P. 2013. Fossiles de la Préhistoire charentaise. Saintes : Le Croît Vif.

Nekvasilova O. 1973. The brachiopod genus Bohemirhynchia gen.n. and Cyclothyris McCoy (Rhynchonellidae) from the Upper Cretaceous of Bohemia. Sbornik Geologickych Vèd (Paleontologie) 15: 75-117.

Orbigny (d') A. 1847-1851. Paléontologie Française. Description zoologique et géologique des animaux mollusques et rayonnés fossiles de France. Terrains Crétacés 4, Texte: 1-157, ArthusBertrand (Ed.); Atlas: pls. 490-525, V. Masson, Paris (Ed.).

Owen EF. 1962. The brachiopod genus Cyclothyris. Bulletin of the British Museum (Natural History) (Geology) 7: 37-63.

Owen EF. 1988. Cenomanian brachiopod from the Lower Chalk of Britain and northern Europe. Bulletin of the British Museum (Natural History) (Geology) 44: 65-175.

Péron A. 1877. Observations sur la faune des Calcaires à Échinides de Rennes-les-Bains et sur quelques fossiles du terrain Crétacé supérieur. Bulletin de la Société géologique de France 3: 499-535.

Platel JP. 1977. Le Campanien stratotypique dans le synclinal de Saintes (Charentes); Lithostratigraphie, géomorphologie et biozonation. Bulletin du Bureau de Recherche Géologique et Minière section 1, 4: 261-276.

Platel JP. 1982. Notice explicative de la feuille Montmoreau. Carte géologique de la France à 1/50 000. Bureau de Recherches Géologiques et Minières 733: 1-43.

Popiel-Barczyk E. 1977. A further study of Albian-Cenomanian brachiopods from the environs of Annopol on the Vistula with some remarks on related species from the Cracow region, Poland. Prace Muzeum Ziemi, Warszawa 26: 25-54.

Radulović V, Motchurova-Dekova N. 2002. The rhynchonellide brachiopod Cyclothyris? globata (Arnaud, 1877) from the Santonian-Campanian of Pannonides, Carpatho-Balkanides and Dinarides (southeastern Europe). Geološki anali Balkanskoga poluostrva 64: 107-135.

Rzhonsnitskaia MA. 1956. Systematization of Rhynchonellida. $X X$ Congreso Geológico Internacional, Mexico, Resúmenes de los Trabajos presentados, Report, 20, pp. 125-126.

Schrøeder AE, Lauridsen BW, Surlyk F. 2017. Ecophenotypic asymmetry in the middle Danian brachiopod Obliquirhynchia flustracea caused by adaptation to attachment on the Coral Dendrophyllia candelabrum. Lethaia 51: 86-95.

Schumann D. 1976. Biotop-abhängige Gehäuse-Variation bei Terebratella transversa (Brachiopoda, recent). Zentralblattl für Geologie und Paläontologie 2: 422-424.

Schumann D. 1991. Hydrodynamic influences in brachiopod shell morphology of Terebratalia transversa (Sowerby) from the San Juan islands, USA. In: MacKinnon D, Lee DE, Campbell JD, eds. Brachiopods through time. Proceedings of the 2nd International Brachiopod Congress, Dunedin, New Zealand. Rotterdam, pp. 265-271.

Sénesse P. 1937. Contribution à l'étude du Crétacé Supérieur des Corbières méridionales. Toulouse: Douladoure.

Sowerby J. 1829. The Mineral Conchology of Great Britain. Volume 6. London: Taylor.

Stern CD. 2002. Fluid flow and broken symmetry. Nature 418: 29-30.

Toucas A. 1873. Les terrains crétacés des environs du Beausset (Var). Mémoire de la Société géologique de France Série 2, 9(4): 1-65, 1 carte géologique, Paris.

Toucas A. 1880. Mémoire du terrain Crétacé des Corbières et comparaison du terrain Crétacé Supérieur des Corbières avec celui des autres bassins de la France et de l'Allemagne. Bulletin de la Société géologique de France 3(8): 39-87.

Toucas A. 1885. Note sur les terrains crétacés de la Valdaren aux environs du Beausset. Bulletin de la Société géologique de France 3, 14(7): 519-523.

Tronchetti G. 1981. Les Foraminifères crétacés de Provence (AptienSantonien). Systématique, Biostratigraphie, Paléoécologie-Paléogéographie. Thèse de Doctorat d'État, Marseille : 1-447 [unpublished].

Vasseur G. 1894. Compte-rendu d'excursions géologiques aux Martigues et à l'Estrague. Bulletin de la Société géologique de France 3(22): 413-443.

Cite this article as: Gaspard D, Charbonnier S. 2019. The debated question of asymmetrical rhynchonellids (Brachiopoda, Rhynchonellida): examples from the Late Cretaceous of Western Europe, BSGF - Earth Sciences Bulletin 191: 1. 